\title{
Affricating ejective fricatives: The case of Tigrinya
}

\author{
Ryan K. Shosted \\ University of Illinois at Urbana-Champaign \\ rshosted@illinois.edu \\ Sharon Rose \\ University of California, San Diego \\ rose@ling.ucsd.edu
}

The production of an ejective fricative involves an aerodynamic dilemma. An ejective requires increased intraoral air pressure, while a fricative requires air to be continuously vented through a narrow constriction. This venting may defeat the pressure increase. Because ejectivity is realized by forming a complete oral closure, we hypothesize that complete closure (i.e. affrication) may also typify ejective fricatives in some languages. We test this hypothesis through an acoustic production experiment with speakers of Tigrinya. We find substantial evidence that Tigrinya /s'/ is commonly realized as [ts'] and comment on the plausibility of affrication as a general strategy for the realization of ejective fricatives.

\section{Introduction}

\subsection{An aeroacoustic confound revisited}

Ejective fricatives are relatively rare sounds in the world's languages. In the UCLA Phonological Segment Inventory Database (UPSID-PC) (Maddieson \& Precoda 1991), only ten of 451 languages $(2.2 \%)$ are reported to have an ejective fricative. The languages with ejective fricatives reported in this database are:

Acoma (Keres) - Miller 1966

Berta (Nilo-Saharan) - Triulzi, Dafallah \& Bender 1976

Dakota (Siouan) - Boas \& Deloria 1939

Kabardian (Caucasian) - Kuipers 1960

Koma (Adamawa-Ubangi) - Tucker \& Bryan 1966

Mazahua (Oto-Manguean) - Spotts 1953

Soqotri (South Arabian) - Leslau 1938, Johnstone 1975

Tlingit (Na-Dene) - Story \& Naish 1973, Swanton 1911

Wichita $^{1}$ (Caddoan) - Garvin 1950, Rood 1975

Yuchi - Crawford 1973, Ballard 1975

\footnotetext{
${ }^{1}$ Although Wichita is listed as a language with ejective fricatives, Garvin (1950) and Rood (1975) report only sequences of /C?/. These appear to have been interpreted as ejectives by Maddieson (1984) and Maddieson \& Precoda (1991).
} 
To the UPSID-PC list, one might add the following:

Adyghe, Bagwali (or Bagwalal), and Karata (Caucasian) - Catford 1992

Hausa $^{2}$ (Chadic) - Ladefoged \& Maddieson 1996, Newman 2000, although see Lindsey, Hayward \& Haruna 1992

Mehri, Harsusi, Bathari, Hobyot, Jibbali (or Shehri) (SouthArabian) - Simeone-Senelle 1997

Upper Necaxa Totonac (Totonac-Tepehua) - Beck 2006

Yapese (Oceanic) - Jensen 1977, Maddieson 1998

Amharic (Ethio-Semitic) - Leslau 1995

Tigre (Ethio-Semitic) - Palmer 1962, Raz 1983

Tigrinya (Ethio-Semitic) - Leslau 1939, 1941

This additional list is based on a general survey of the literature on ejective fricatives, not on an exhaustive survey of language grammars.

The presence of an ejective fricative in a language seems almost always to imply the presence of at least one other ejective obstruent. In all UPSID-PC languages the presence of an ejective fricative implies the presence of at least one ejective stop. One exception to this generalization is Upper Necaxa Totonac (Beck 2006; not reported in UPSID-PC), which has ejective fricatives but no ejective stops or ejective affricates. Like languages with ejective fricatives, UPSID-PC languages with ejective affricates fit neatly within the set of languages with ejective stops. The only exception is Iraqw, a Cushitic language of Tanzania which has two ejective affricates but no ejective stop (nor an ejective fricative) (Whiteley 1958, see also Mous 1993). ${ }^{3}$ Of the ten UPSID-PC languages with ejective fricatives, only three lack ejective affricates: Berta, Koma, and Soqotri. Conversely, of the 59 languages that have ejective affricates, only seven have ejective fricatives (see Figure 1). Thus, the chance of a language having ejective fricatives seems to increase slightly if the language also has ejective affricates. Of the seven languages that have both ejective fricatives and affricates, six (Acoma, Dakota, Mazahua, Tlingit, Wichita, and Yuchi) have affricates and ejectives at the same place of articulation.

Ejectives are produced by trapping air between the tightly adducted vocal folds and a constriction at an oral place of articulation. To produce an ejective, the larynx should be raised, thereby compressing the air in the supralaryngeal cavity (Ladefoged 1993: 130). Upon release, 'the entrapped high-pressure air will momentarily burst forth in a short sharp explosion' (Catford 2001: 22).

The release of the oral closure results in a sudden outflow of air (a glottalic egressive airstream), along with a characteristic burst of acoustic energy. After this, the laryngeal closure is released, the suprahyoid musculature relaxes, thus lowering the larynx, and pulmonic egressive airflow may course through the glottis.

The production of an ejective fricative involves an aeroacoustic dilemma. Two competing demands, stated here as directives, must be satisfied: (i) Ejectivity: Substantially increase air pressure above the larynx (to a degree greater than expected during pulmonic egressive obstruents); (ii) Frication: Vent air continuously through a narrow constriction. The venting required of a fricative may defeat the increase in pressure required of an ejective.

Maddieson $(1997,1998)$ has put forward two mechanisms for satisfying these demands. First, he proposes reducing the size of the constriction between oral articulators to increase

\footnotetext{
${ }^{2}$ Maddieson \& Precoda (1991) characterize the Hausa fricative as 'laryngealized' and place it, by implication, in the same category as fricatives in Korean, Siona, Southern Nambiquara, Sui, and Wapishana.

${ }^{3}$ Mous (1993:17) describes the uvular transcribed [q] as an affricate, which is, however, realized as a stop in pre-consonantal position, and optionally as an ejective stop word-initially.
} 


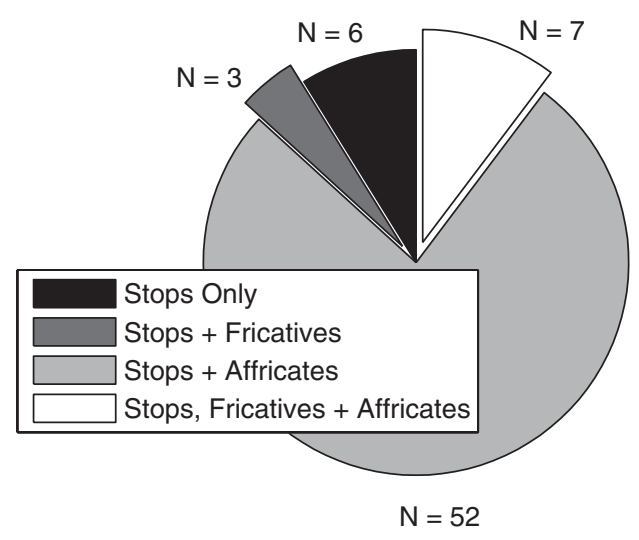

Figure 1 Languages with ejective stops in UPSID-PC (Maddieson \& Precoda 1991) categorized by the presence/absence of ejective fricatives and/or affricates.

intraoral pressure. Thus, the fricative can be produced exclusively on the outflow of air trapped above the larynx, albeit at some cost to net flow and therefore duration. The ejective fricatives of Tlingit, with an oral constriction narrower than that of pulmonic fricatives, are of this type. They allow intraoral air pressure to achieve a higher peak than is found during pulmonic fricatives but the duration is reduced, since the supralaryngeal cavity volume is much smaller than the volume of the lungs (Maddieson, Smith \& Bessell 2001).

Maddieson's $(1997,1998)$ second proposal for resolving the aeroacoustic dilemma is to sequence frication and glottal constriction, as in Yapese. This proposal raises the question of whether such a sound still qualifies as an ejective in the classic sense, e.g. that of Catford (2001). After all, frication is not produced simultaneously with glottal closure, nor is the larynx necessarily raised to increase pressure during the fricative. Indeed, Maddieson (1998) concludes that Yapese ejective fricatives are not ejectives at all, but a sequence of e.g. /f/ +/?/ (see Section 1.3.5 for further discussion of Yapese).

Beyond these two mechanisms, another may be posited: Frication may be preceded by a period of oral closure, allowing time for air pressure to build (we will refer to this as the AFFRICATION HYPOTHESIS). Closure plus frication is characteristic of affricates, not fricatives, and thus raises the question of whether ejective fricatives realized in this way have crossed an ontological boundary. Pre-release closures have been reported in the literature for ejective fricatives in Amharic (Demolin 2002) and Kabardian (Gordon \& Applebaum 2006) with little comment.

The purpose of this paper is to further elaborate the affrication hypothesis through an acoustic study of the alveolar ejective fricative in Tigrinya. The results will suggest that this fricative is often realized as an affricate, thus explaining historical confusion about the transcription of the sound, as well as dialectal variation in its realization. More generally, the results will suggest that affrication is a phonetically natural path in the evolution of ejective fricatives.

\subsection{Tigrinya and its ejective fricatives}

Tigrinya is a North Ethio-Semitic language spoken in northern Ethiopia and Eritrea. The Ethio-Semitic (also termed Ethiopian Semitic) family is classified as South Semitic, part of the larger West Semitic branch (Faber 2007). The consonant inventory for Tigrinya is shown in Table 1. There are five ejectives: /t' $k^{\prime} k^{w}$ ' s' ty'/, 
Table 1 Phonemic obstruents in Tigrinya.

\begin{tabular}{|c|c|c|c|c|c|c|c|c|}
\hline & \multirow{2}{*}{$\begin{array}{l}\text { Bilabial/ } \\
\text { Labiodental }\end{array}$} & \multirow[b]{2}{*}{ Alveolar } & \multirow{2}{*}{$\begin{array}{l}\text { Palato- } \\
\text { alveolar }\end{array}$} & \multicolumn{2}{|c|}{ Velar } & \multirow[b]{2}{*}{ Pharyngeal } & \multirow[b]{2}{*}{ Glottal } \\
\hline & & & & & plain & labialized & & \\
\hline \multirow[t]{3}{*}{ Stop } & voiceless & (p) & $\mathrm{t}$ & & $\mathrm{k}$ & $\mathrm{k}^{\mathrm{w}}$ & & $?$ \\
\hline & voiced & b & d & & $\mathrm{g}$ & $g^{w}$ & & \\
\hline & ejective & (p') & $t^{\prime}$ & & $\mathrm{k}^{\prime}$ & $\mathrm{k}^{\mathrm{w}}$, & & \\
\hline \multirow[t]{3}{*}{$\begin{array}{l}\text { Fricative/ } \\
\text { Affricate }\end{array}$} & voiceless & $\mathrm{f}$ & $\mathrm{S}$ & $\int_{(\mathfrak{t})}$ & & & $\hbar$ & $\mathrm{h}$ \\
\hline & voiced & & $\mathrm{Z}$ & $\begin{array}{l}\text { (3) } \\
\text { d3 }\end{array}$ & & & @ & \\
\hline & ejective & & $\mathrm{s}^{\prime}$ & ț & & & & \\
\hline
\end{tabular}

All consonants in Tigrinya, including the ejectives, may be geminate/long, although the 'guttural' sounds /h h ? I/ appear as geminate in limited circumstances (Berhane 1991). ${ }^{4}$ The sounds [p] and [ $\mathrm{g}$ ] appear in loanwords, primarily from Italian and English, whereas the sound [p'] appears in Greek loanwords. [3] is uncommon and varies with $/ \mathrm{d} /$. The voiceless velar stop $/ \mathrm{k} /$ is realized as $[\mathrm{x}]$ in post-vocalic position, and the ejective $/ \mathrm{k}$ ' has a post-vocalic allophone commonly transcribed as [x'] (Leslau 1941, Schein 1981, Kenstowicz 1982, Denais 1990, Fitzgerald 2006). The actual production of this sound is reported as uvular (Fre Woldu 1985), but whether it is ejective is unclear. An acoustic and aerodynamic investigation of its properties is being undertaken by the current authors.

[ $\left.\mathrm{s}^{\prime}\right]$ is described as an alveolar ejective fricative in the standard linguistic and grammatical literature on Tigrinya and usually transcribed with the letter $\langle\mathrm{s}\rangle$ and a diacritic to indicate glottalization (Leslau 1941, Pam 1973, Denais 1990, Berhane 1991, Kogan 1997, Tewolde 2002. However, Denais (1990: 32) notes that $/ \mathrm{s} /$ is a fricative but has a free variant $\left[{ }^{t} \mathrm{~s}\right.$ ']. The sound is also transcribed as [ts'] without comment by Palmer (1966) and Walther (1999). Finally, Fre Woldu (1985: 4), a native Tigrinya speaker, uses a fricative transcription, but places the sound in the affricate section of the obstruent chart. Berhane (1991), another native speaker of Tigrinya, calls it a fricative. These variable transcriptions lend credence to the hypothesis that Tigrinya's ejective fricative may be realized with initial closure.

Alternation of [s'] with [ts'] is reported for other languages. In Hausa, the digraph $\langle\mathrm{ts}\rangle$ is used in the standard orthography for what Jaggar (2001) describes as an ejective alveolar sibilant, but it is listed as an affricate in the consonant chart. Leslau (1957: 156) reports that in the Amharic dialect of Godjam, [s'] is 'often definitely pronounced as affricate [ts']'. Bender (1992) reports that [s'] alternates with [ts'], but also tends to be realized as [t'] in the Shewa dialect of Amharic. Indeed, Amharic cognates of Tigrinya words containing [s'] generally show [t'] or its palatalized version [t'] (Leslau 1987), and some words show variation, e.g. [s'omə] [t'omə] 'he fasted' (Tadesse 1992, Leslau 1995). In Dime (Fleming 1990), [s']

\footnotetext{
${ }^{4}$ We choose to follow the convention of Ladefoged \& Maddieson (1996: 92), who use the terms 'geminate' and 'long' synonymously for unitary consonants and contrast these with sequences of identical consonants. Unlike Crystal (2003: 196), they do not use the term 'geminate' to refer to a sequence of consonants. In fact, they contrast 'geminates' with 'sequences' on a number of occasions, e.g. 'Unlike a sequence, geminates ... may not be separated by an epenthetic vowel' and 'Geminate affricates are very clearly different from an affricate sequence' (p. 92). Crystal (2003: 196) claims that 'a geminate sequence cannot be regarded as simply a "long" consonant', suggesting that in his view geminates are sequences and 'long' consonants are unitary elements. Pycha (2009: 5) refers to 'geminates' from various sources, including '[s]uffix-conditioned geminates' as well as 'those created by juxtaposition of two consonants, those created by assimilation, [and] those which exist underlyingly'. Pycha's (2009) definition of 'geminate' thus appears to include both sequences and 'underlyingly' long consonants.
} 
and [ts'] pronunciations cannot be distinguished, at least in initial position (although Seyoum (2008) does not mention this variation). Savà (2005: 23) reports that the ejective affricate /ts'/ in Ts'amakko has an ejective fricative [s'] as a free variant. In Lowland Oaxaca Chontal (Maddieson, Avelino \& O'Connor 2009), /s'/ is realized as [ts'] or [ts?] with a few tokens of [s?] or [?s] (see Section 1.3.6 for more discussion).

There is also historical and dialectal evidence which may support the affrication hypothesis for Tigrinya. First, Steiner (1982) proposes that West Semitic *S (Șade) should be reconstructed as a glottalized affricate $\left[\mathrm{ts}^{2}\right]$ rather than a fricative, and Faber (1985) supports and extends this position to Proto-Semitic. Reflexes of this sound appear as [ts] in Modern Hebrew, as $\left[\mathrm{S}^{\mathrm{C}}\right]$ in Arabic, and as [s'] in Tigrinya, e.g. [his $\left.\mathrm{S} a: r\right]$ (Arabic) 'enclosure' [xatsər] (Modern Hebrew) 'enclosure, courtyard', [has'orə] (Tigrinya) 'make a fence'. Arabic acquired secondary pharyngealization, whereas Hebrew lost glottalization. These variable reflexes could stem from an affricate pronunciation of an ejective fricative. Second, rural dialects of Tigrinya favor a palato-alveolar affricate [ $\mathrm{f}^{\prime}$ ] instead of [s'] in some lexical items: e.g. [has'วrə] [hatf'ərə] 'become short', [k'wins'i] [k'w intf'i] 'flea' or [s'əmmərə]

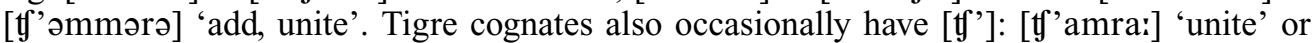
[k'ars'a:] [k'art' 'a:] 'slice, cut off' (Tigrinya [k'ərəs'ə]) (Leslau 1987). Ullendorff (1955) and Voigt (1988) propose that this alternation is a type of palatalization due to influence from rounded vowels by way of labial consonants, parallel to a [s $\left.\sim \int\right]$ alternation. Although the viability of the rounding trigger may be questioned, it is clear that [s'] alternates not with [S'], but with an affricate.

Fre Woldu (1985) analyzed the properties of voiceless, voiced and ejective stops in Tigrinya, but not the ejective fricative $/ \mathrm{s} \%$. He found that the main characteristic of ejective stops, in relation to pulmonics, was a longer burst release followed by a period of silence preceding the vowel. In perceptual experiments, native listeners reliably cued into this long silent period in order to distinguish ejective and plain voiceless stops.

Kingston (1985) analyzed larynx movement for Tigrinya stops. He observed 4-6 mm of laryngeal displacement during the ejective consonants but commented that larynx elevation is variable across speakers and is too slow and ill-timed with oral closure and release to fully explain the decreased volume of the oral cavity necessary for ejectives. No data on the ejective fricatives of Tigrinya were reported.

\subsection{The phonetics of ejective fricatives: A cross-linguistic perspective}

In this section we present observations about ejective fricatives in those languages where the sounds have been described instrumentally.

\subsubsection{Amharic}

Demolin $(2002,2004)$ reports the main acoustic, aerodynamic, and articulatory characteristics of the ejective fricative /s'/ in Amharic, a South Ethio-Semitic language closely related to Tigrinya. ${ }^{5}$ The duration of the ejective fricative, both singleton and geminate, is always shorter than that of the plain fricative. The frication noise of a plain fricative has constant amplitude, but for ejectives there is a gradual increase in amplitude during constriction, and $12 \mathrm{~ms}$ (geminate) or $30 \mathrm{~ms}$ (singleton) of glottal lag before vowel onset that is not present in pulmonic fricatives. There is no discussion of a preceding silent interval characteristic of affrication, though there is one example of a recorded ejective fricative whose waveform is characterized by a (nearly) silent interval (Figure 4 in Demolin 2002: 469). Intraoral air pressure was measured using a small plastic tube inserted through the nasal cavity into the oro-pharynx, and oral airflow was measured using a silicone rubber mouthpiece, both pieces of equipment connected to a Physiologia workstation (Bucella et al. 2000: 449-450; Teston $\&$ Galindo 1990). Intraoral air pressure for the ejective rises rapidly with a dramatic decrease

\footnotetext{
${ }^{5}$ UPSID-PC (Maddieson \& Precoda 1991) reports only ejective affricates for Amharic.
} 
right after the peak, whereas the plain fricative shows a slower increase and decrease. Peak intraoral pressure is twice as high for ejectives as it is for pulmonics, but subglottal pressure is not significantly different.

Electropalatography (EPG) and static palatography reveal that the Amharic ejective fricative has wider contact in the alveopalatal region, which Demolin (2002: 472) interprets as a reduction in the overall size of the oral cavity, probably intended to reduce the supralaryngeal cavity size and thereby maximize pressure. There is an alveopalatal closure observed for both singleton and geminate ejective fricatives. Demolin (2002: 473) concludes that oral and glottal closures are simultaneous, but oral constriction is released before glottal closure.

\subsubsection{Tlingit}

Tlingit, a Na-Dene language spoken in the Pacific Northwest coast of North America has six ejective fricatives, /s' '’ $x^{\prime} x^{w} \chi^{\prime} \chi^{w} /$, five ejective stops, /t' $k^{\prime} k^{w}, q^{\prime} q^{w} \% /$, and three ejective affricates, /ts' ty' ty'/ (Maddieson et al. 2001). All of these sounds have plain pulmonic counterparts. Maddieson et al. (2001) present both acoustic and aerodynamic data for the ejective fricatives. Word-initial ejective fricatives are characterized by an approximately $46 \mathrm{~ms}$ silent interval following a word-initial fricative, punctuated by a release (of glottal closure) into the vowel. Word-final fricatives are flanked by silent intervals, and there is a detectable release burst approximately $39 \mathrm{~ms}$ after the silent period. The noisy portion of the fricative is significantly shorter in an ejective fricative than a pulmonic fricative (word-initial $148 \mathrm{~ms}$ vs. $222 \mathrm{~ms}$ and word-final $127 \mathrm{~ms}$ vs. $301 \mathrm{~ms}$, respectively), and the noise is 'scrapy' (broken into a series of pulses). Maddieson et al. (2001: 159) postulate that this scrapy quality (which they did not observe in $/ \mathrm{s}^{\prime} /$ ) occurs due to intermittent closures of the oral channel, possibly related to the presence of saliva in a very narrow constriction. The scrapy quality may also be caused by friction at the aryepiglottic folds (Esling 1996, Moisik 2008). Maddieson et al. (2001: 172) explicitly reject the possibility that the scrapy quality is a glottal phenomenon. Given the high intraoral pressure observed during ejective fricatives, they argue that glottal pulsing would require an 'improbably high' level of subglottal pressure. Although pulmonic fricatives undergo final lengthening in Tlingit, ejective fricatives do not.

Intraoral air pressure data was recorded by speakers holding a narrow plastic tube positioned between the lips with the open end resting against the center of the hard palate. Pressure behind the constriction was detected through the tube and recorded using Macquirer hardware and software. A series of calibration recordings were then made using a U-tube manometer. The intraoral pressure trace for Tlingit ejective fricatives is parabolic, with a high peak level between $14 \mathrm{hPa}$ and $17 \mathrm{hPa}$, but without a sustained peak, compared with between $5.2 \mathrm{hPa}$ and $8.6 \mathrm{hPa}$ for pulmonic fricatives. Air pressure is presumably maintained by forcing air through a narrower supraglottal constriction, which could also explain the scrapy, pulsing quality of the fricative noise. Maddieson et al. (2001) propose that the silent periods flanking frication are due to glottal closure overlapping the entire fricative. The silent interval before frication appears to occur variably, as illustrated by a word with a word-medial ejective fricative uttered by two different native speakers (Dauenhauer \& Dauenhauer 1991; see Figure 2). It is not clear why the closure preceding frication is interpreted as glottal rather than oral. No data on the ejective affricates were reported to test how contrast is realized between the fricative/affricate pairs [s'] and [ts'] or [''] and [t''].

\subsubsection{Kabardian}

Kabardian (Gordon \& Applebaum 2006) is a Northwest Caucasian language which has three ejective fricatives: /f' $\int^{\prime} \mathrm{y}^{\prime} /$ as well as an ejective affricate $/ \mathrm{ts}^{\prime} /$ and a series of ejectives stops: /p' t' $\mathrm{k}^{\mathrm{j}}$ ' $\mathrm{k}^{\mathrm{w}}, \mathrm{q} \%$. Gordon \& Applebaum (2006) found that the ejective fricatives had shorter frication duration (average $130 \mathrm{~ms}$ ) than their pulmonic counterparts (191 ms) in word-initial position. Frication was often characterized by pulsing noise, as in Tlingit. Ejective fricatives were characterized by a long VOT lag, or silent period before vowel onset, and were less intense than the pulmonics. Comparison of palatograms for the alveopalatal 

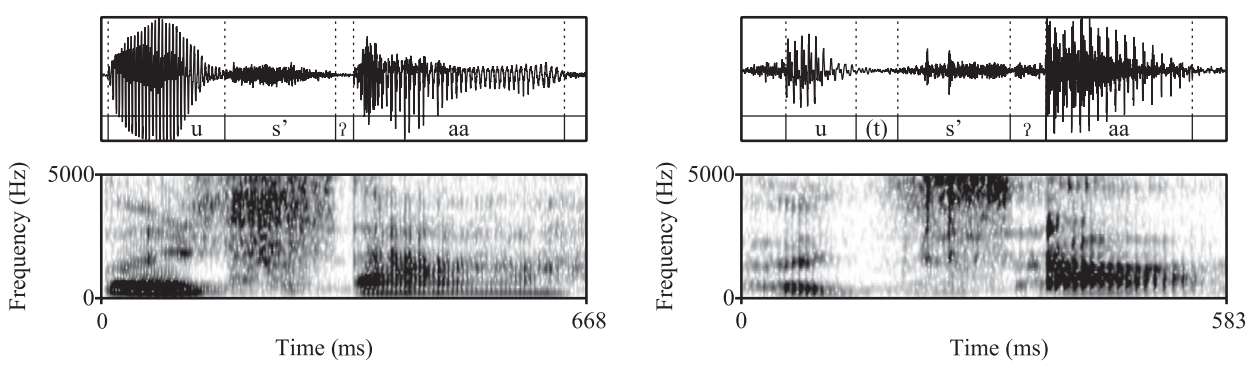

Figure 2 The Tlingit word ús'aa 'soap' produced by a female speaker (left) and a male (right), taken from audio files in Dauenhauer \& Dauenhauer (1991). The second token is marked by a nearly silent closure before the onset of frication [(t)]. Both are marked by a period of irregular vibration or near silence after the frication, transcribed here as [?].

pulmonic and ejective fricatives suggests that the ejective fricative is produced with a narrower constriction with wider contact and a narrower opening in the anterior portion of the mouth. One palatogram even showed evidence of alveopalatal closure prior to frication in the ejective. Acoustic evidence of closure prior to frication was found commonly with the lateral fricative. Aerodynamic data, using the same plastic tube methodology as in Maddieson et al. (2001), revealed a high intraoral pressure peak at the point of release. No data on the Kabardian ejective affricate $/ \mathrm{ts}^{\prime} /$ were reported.

\subsubsection{Upper Necaxa Totonac}

Upper Necaxa Totonac is a member of the isolate Totonac-Tepehua family spoken in Puebla, Mexico (Beck 2006). It has three ejective fricatives: /s' $\int^{\prime}$ ' $\%$, but no ejective stops. Beck (2006) collected both acoustic and aerodynamic data for the ejective fricatives. No details on the aerodynamic methodology are provided other than mention of an airflow mask and Macquirer 6.0 airflow analysis software. The peak value of intraoral air pressure was not different between ejectives and pulmonics, but the intraoral pressure does peak earlier for ejectives than for pulmonic fricatives. Air flow reaches its peak following the intraoral pressure for ejectives, but earlier than the intraoral pressure peak for pulmonics. As for duration of frication, pulmonic fricatives are shorter than ejective fricatives, the reverse of the pattern observed in Amharic, Tlingit and Kabardian. There is a brief hiatus of approximately $9 \mathrm{~ms}$ following frication for the ejective before vowel onset, but on the spectrograms provided, it is rather noisy. ${ }^{6}$

\subsubsection{Yapese}

Maddieson (1997, 1998) reports that in Yapese, an Austronesian language spoken in the Micronesian state of Yap, the ejectives $/ \mathrm{f}^{\prime} /$ and $/ \theta^{\prime} /$ have similar noise durations. Intraoral pressure is the same in plain and glottalized fricatives, and only differs in that the pressure rise occurs earlier in the ejective. Maddieson (1998) concludes that they are not ejectives but a sequence of frication and glottal constriction.

\subsubsection{Lowland Oaxaca Chontal}

Oaxaca Chontal is reported to have ejective obstruents /f' '' ts' t' k'/ (Waterhouse 1962,

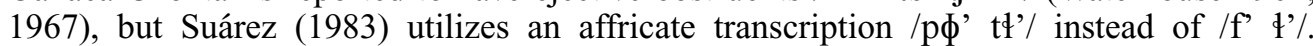
Maddieson et al. (2009) argue that the phonemic fricative notation may have some credence in that the 'glottalized' obstruents can be derived from fricatives via a plural formation strategy. One method of plural formation is to add a glottal stop to words ending in vowels,

\footnotetext{
${ }^{6}$ Beck reports $0.943 \mathrm{~ms}$, but then states that $3.44 \mathrm{~ms}$ for pulmonics is shorter, so it is assumed that the decimal point is misplaced or the units were misprinted.
} 
or glottalization to words ending in sonorants and fricatives (there are no word-final stops or affricates). Yet, there is considerable variation in how these derived glottalized fricatives are realized, as well as underived glottalized obstruents: stop, fricative and affricate productions are attested with various forms of glottalization. Maddieson et al. (2009) report descriptive acoustics and did not take any aerodynamic measurements. For velars, a stop [k'] is the most common production, whereas coronal obstruents are typically realized as affricate [ts' tł']. Affricate ejectives are characterized by silent closure followed by frication, a release burst and a period of (nearly) silent glottal closure. Fricative realizations can involve pre- or post-glottalization, described as glottal constriction sequenced with frication (e.g. [s?] and $[? \mathrm{~s}])$; these tokens lack the glottal closure and release burst characteristic of ejectives. The pronunciation [f?] is the most common realization for the labial, although affricate [pf'] is also attested. From 630 tokens from eight speakers, only two tokens exhibited an ejective fricative realization: [']']. Therefore, it appears that Oaxaca Chontal does not have ejective fricatives per se, only ejective affricates, or glottal-fricative sequences, as in Yapese. The data from Oaxaca Chontal therefore lend credence to the hypothesis that ejective fricatives present aeroacoustic challenges, and one means of solving this problem is by realizing the ejective fricative via affrication.

\subsubsection{Summary}

In conclusion, ejective fricatives are characterized by shorter frication duration than pulmonic fricatives (except for Upper Necaxa Totonac), with a following (near-)silent lag before vowel onset, presumably associated with the time that it takes for the larynx to drop and regular vocal fold vibration to initiate under an egressive pulmonic airflow regime. The frication itself is often described as 'scrapy' or 'pulsing', perhaps indicative of an oral constriction that opens and closes quickly. Ejective fricatives generally show higher intraoral pressure peaks, typically occurring earlier than they do during pulmonics. High supralaryngeal cavity pressure is of course a hallmark of ejectives. The timing of the peak suggests that pressure builds more slowly in pulmonic fricatives, a difference that is likely to have acoustic consequences as well. Upper Necaxa Totonac is an exception to this intraoral pressure pattern. Palatograms reveal wider contact and narrower constriction, and in some cases evidence of total alveolar or alveopalatal occlusion, particularly in Amharic. Silence preceding frication is sporadically reported and was interpreted as glottal closure (without further comment) for Tlingit (Maddieson et al. 2001). This can be seen on the right-hand side of Figure 2. A summary of these characteristics for four languages, excluding Yapese and Lowland Oaxaca Chontal (because their so-called ejective fricatives have been interpreted as a sequence of fricative plus glottal stop), is shown in Table 2. None of the languages surveyed had geminate ejective fricatives.

\subsection{The problem}

The motivation for our study is based on several observations: (i) most languages that have ejective fricatives also have ejective affricates (see Figure 1); (ii) Tigrinya ejective fricatives do not contrast with homorganic affricates, but the fricatives are occasionally transcribed or described as affricates and dialectal variation along these lines is reported; (iii) linguopalatal occlusion has been reported for the ejective fricative of Amharic, a related language; and (iv) the buildup of intraoral pressure during ejective consonants can be achieved most effectively by creating a complete supralaryngeal occlusion while raising the larynx. Thus, our study will investigate the AFFRICATION HYPOTHESIS, i.e. there is a complete supralaryngeal occlusion before the onset of frication in Tigrinya ejective fricatives. If this hypothesis is correct, we expect that ejective fricative /s'/ will manifest a silent interval preceding fricative release and that pulmonic fricative /s/ will not. We will report measures of this pre-release silent interval as 'closure duration' throughout the paper. 
Table 2 Characteristics of ejective fricatives compared to pulmonic fricatives ( $n / r=$ not recorded or reported).

\begin{tabular}{|c|c|c|c|c|c|}
\hline & & $\begin{array}{l}\text { Amharic } \\
\text { s' }\end{array}$ & $\begin{array}{l}\text { Tlingit } \\
\mathrm{s}^{\prime}{ }^{\prime}{ }^{\prime} \\
\mathrm{x}^{\prime} \mathrm{x}^{\mathrm{w}}, \\
\chi^{\prime} \chi^{\mathrm{w}},\end{array}$ & $\begin{array}{l}\text { Kabardian } \\
\text { f' J' 4', }\end{array}$ & $\begin{array}{l}\text { Upper Necaxa } \\
\text { Totonac } \\
\text { s' J' ', }\end{array}$ \\
\hline \multirow[t]{2}{*}{ Frication } & Shorter frication & $\sqrt{ }$ & $\sqrt{ }$ & $\sqrt{ }$ & no \\
\hline & Scrapy frication & $n / r$ & $\sqrt{ }$ & $\sqrt{ }$ & $n / r$ \\
\hline \multirow[t]{2}{*}{ Silent interval } & Pre-frication silence & $\sqrt{ } ?$ & $\sqrt{ }$ & $\sqrt{ }$ & $n / r$ \\
\hline & Glottal lag/ laryngealization & $\sqrt{ }$ & $\sqrt{ }$ & $\sqrt{ }$ & $\sqrt{ }$ \\
\hline Amplitude & Constant amplitude & $\sqrt{ }$ & $n / r$ & $n / r$ & $n / r$ \\
\hline Intensity & Low intensity & $n / r$ & $n / r$ & $\sqrt{ }$ & $n / r$ \\
\hline \multirow[t]{3}{*}{ Intra-oral air pressure } & High pressure peak & $\sqrt{ }$ & $\sqrt{ }$ & $\sqrt{ }$ & no \\
\hline & Rapid rise & $\sqrt{ }$ & $\sqrt{ }$ & $\sqrt{ }$ & no \\
\hline & Short duration peak & $\sqrt{ }$ & $\sqrt{ }$ & $\sqrt{ }$ & no \\
\hline Air flow & Later peak & $n / r$ & $n / r$ & $\sqrt{ }$ & $\sqrt{ }$ \\
\hline Linguo-palatal contact & $\begin{array}{l}\text { Narrower constriction, wider } \\
\text { contact, and complete occlusion }\end{array}$ & $\sqrt{ }$ & $n / r$ & $\sqrt{ }$ & $n / r$ \\
\hline
\end{tabular}

We also hypothesize that closure duration will be longer in the geminate ejective fricative than the singleton. Longer closure duration is the expected measure of phonological length contrast for affricates (Pycha 2009).

As mentioned above, there is abundant dialectal and transcriptional evidence suggesting that the ejective fricative of Tigrinya varies with an affricate. Furthermore, Demolin's (2002, 2004) aerodynamic and EPG measures of $/ \mathrm{s} /$ in Amharic, a closely-related language, are indicative of complete linguopalatal closure. In addition, if closure is manipulated to convey length differences for the /s'/ vs. / $\mathrm{s}^{\prime} /$ contrast as it does for affricates, then this further reinforces our interpretation of the closure as linguopalatal. Nevertheless, there is the possibility that the closure could be interpreted as glottal. Maddieson et al. (2001) assume this intepretation for Tlingit $/ \mathrm{s} /$ where increased intraoral pressure is interpreted as evidence of increased supraglottal constriction but not full linguopalatal closure. Despite the absence of aerodynamic or physiological data for Tigrinya $/ \mathrm{s} \%$, we believe that the facts are more in line with a supralaryngeal closure interpretation.

We will investigate other acoustic properties (besides closure duration) that differentiate the two types of fricatives from each other and which also differentiate Tigrinya's ejective fricative from its ejective affricate. These are release duration, preceding and following vowel duration, presence and duration of post-release laryngealization, amplitude rise slope, and rise time. ${ }^{7}$ These measurements will allow us to present a full acoustic profile of intervocalic $/ \mathrm{s}^{\prime} /$ in comparison to the pulmonic fricative and assess its properties as characteristic of either fricative or affricate. We predict that release duration will be shorter for the ejective fricative than the pulmonic fricative, and we anticipate that the presence of laryngealization and perhaps longer laryngealized intervals will signal ejectivity. We make no strong predictions concerning vowel duration. On the one hand, the presence of predicted closure in ejective fricatives may correlate with a shorter preceding vowel. On the other hand, if release duration is shorter for ejective fricatives, then the preceding vowel may be longer. Following vowel duration may adjust for a longer laryngealization period, with shorter vowels following ejectives. The

${ }^{7}$ Following Esling, Fraser \& Harris (2005: 390), we use the term 'laryngealization' to denote harsh or creaky voice phonation. The authors recommend reserving the term 'glottalization' to designate 'secondary articulations involving a glottal stop'. 
affrication hypothesis predicts that, apart from properties associated with alveolar versus palato-alveolar place of articulation differences, $/ \mathrm{s}$ '/ should share characteristics with $/ \mathfrak{f} ' /$ : similar release duration, high amplitude rise slope, and long rise time. Finally, we will discuss the likelihood that affrication is a viable strategy for satisfying the competing aeroacoustic demands involved in the production of simultaneous frication and ejectivity, particularly in languages that lack a corresponding ejective affricate.

\section{Method}

\subsection{Speakers}

Data from five male subjects between the ages of 25 and 45 years were recorded. All subjects were from Asmara, the capital city of Eritrea, and were native speakers of Tigrinya, having left Eritrea after reaching adulthood. All subjects also spoke English and Amharic. In addition, one subject spoke some Blin, a Cushitic language of Eritrea, and another was fluent in Italian. Uncompressed 16-bit wav-files of the subjects' utterances were recorded on a Marantz PMD660 solid state recorder. Recordings took place whenever possible in a sound-attenuated booth but alternatively in a quiet room in a private house. Subjects were recorded using a N/D267a Dynamic Cardioid table-top microphone, positioned approximately 10-12 inches from their mouths. They were instructed to remain as still as possible while speaking. Speech was sampled at $48 \mathrm{kHz}$ for the first four speakers and (inadvertently) at $44.1 \mathrm{kHz}$ for the fifth. Because spectral measures were not included in the analysis the discrepancy in sampling rate, though unfortunate, was not considered problematic.

\subsection{Tokens}

Production consisted of a word list of 183 Tigrinya verb forms drawn from Kane (2000) (137 target items and 46 fillers, including items with test consonants $/ \mathrm{t}$ '/ and $/ \mathrm{J} /$, which do not form part of our analysis here) in a carrier sentence: /tomali Pilu/ 'Yesterday he said'.

These were presented to the subjects in Ethiopic writing using Abyssinica font (www.sil.org):

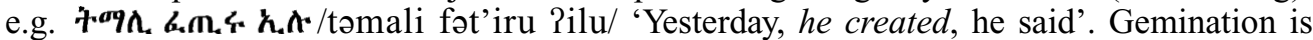
not normally indicated in Ethiopic writing, but can be marked with two dots over a symbol (Leslau 1995). Gemination diacritics were added as appropriate to ensure minimal pairs were

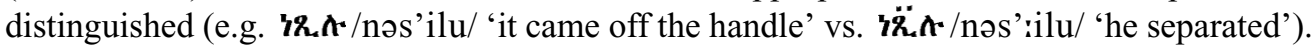
Subjects were given the chance to familiarize themselves with the extra diacritic before beginning the experiment, and subsequently had no trouble with its use. Sentences were randomized and presented to subjects using Microsoft PowerPoint, with four sentences per slide. The investigator controlled slide transitions.

The word list was designed to compare several factors. Five target consonants differing in manner of articulation and airstream mechanism were selected: / $\mathrm{s}^{\mathrm{t}} \mathrm{s}^{\prime} \mathrm{t}^{\prime} \mathbf{t} \boldsymbol{\prime}^{\prime} \%$ (We present statistical results bearing on /s s' ty'/ only.) Note that Tigrinya lacks the pulmonic singleton affricate $/ \mathfrak{t} /$ except in loanwords, chiefly from Italian. Target consonants appeared in word initial position and in intervocalic medial position. Target consonants in medial position were either singleton or geminate. The vowel adjacent to the target consonant (in the antepenultimate syllable) was either low /a/, mid /a/ (slightly fronted) or high $/ \mathbf{i} /$. This vowel followed the target consonant in initial position or preceded it in medial position. In Tigrinya, stress is generally word-final.

Triliteral consonant roots were conjugated in different verbal paradigms to balance vocalic context in the recordings. Tigrinya triliteral verbs are classified into three lexical classes labeled Type A, B, and C (Leslau 1941). Each verb type has a distinctive vowel pattern and consonant gemination pattern. For example, Type B verbs are characterized by gemination of a medial root consonant in most verb forms, whereas Type $\mathrm{C}$ verbs are characterized by 
Table 3 Word types illustrating position and vocalic context of fricatives under investigation.

\begin{tabular}{|c|c|c|c|}
\hline & Singleton & & \\
\hline Pattern & Initial & Medial & \\
\hline \multirow[t]{2}{*}{$\mathrm{CaCiC}-\mathrm{u}$} & s'amiwu & las'iju & 3msg gerundive (Type С) \\
\hline & & Sas'ibu & 3msg gerundive (guttural Type A) \\
\hline $\mathrm{C} ə \mathrm{CiC}-\mathrm{u}$ & s'ogibu & nəs'ilu & 3msg gerundive (Type A) \\
\hline $\mathrm{CiC} \partial \mathrm{C}-\mathrm{u}$ & s'igəbu & nis'əlu & imperative plural (Type A) \\
\hline \multicolumn{4}{|c|}{ Geminate } \\
\hline Pattern & Initial & Medial & \\
\hline CaC:iC-u & & Sas':ix'u & 3msg gerundive (guttural Type B) \\
\hline $\mathrm{CoC}: i C-u$ & & gəs':ibu & 3msg gerundive (Type B) \\
\hline mi-CiC:aC-u & & migis':abu & 3msg infinitive (Type B) \\
\hline
\end{tabular}

Table 4 Distribution of target consonants, speakers, repetitions, subtotals and totals.

\begin{tabular}{|c|c|c|c|c|c|c|c|c|c|}
\hline \multirow[b]{2}{*}{ Consonant type } & \multirow[b]{2}{*}{ Preceding vowel } & \multirow[b]{2}{*}{ Medial singleton } & \multirow[b]{2}{*}{ Medial geminate } & \multicolumn{6}{|c|}{ Speakers and (repetitions) } \\
\hline & & & & S1 (4) & S2 (4) & S3 (3) & S4 (3) & S5 (2) & Totals \\
\hline \multirow[t]{3}{*}{$/ \mathrm{s}^{\prime} /$} & High & 4 & 4 & 32 & 32 & 24 & 24 & 16 & 128 \\
\hline & Mid & 4 & 4 & 32 & 32 & 24 & 24 & 16 & 128 \\
\hline & Low & 4 & 3 & 28 & 28 & 21 & 21 & 14 & 112 \\
\hline \multirow[t]{3}{*}{ /s/ } & High & 4 & 4 & 32 & 32 & 24 & 24 & 16 & 128 \\
\hline & Mid & 4 & 4 & 32 & 32 & 24 & 24 & 16 & 128 \\
\hline & Low & 3 & 3 & 24 & 24 & 18 & 18 & 12 & 96 \\
\hline \multirow[t]{4}{*}{$\mid \mathfrak{t}{ }^{\prime} /$} & High & 3 & 3 & 24 & 24 & 18 & 18 & 12 & 96 \\
\hline & Mid & 3 & 3 & 24 & 24 & 18 & 18 & 12 & 96 \\
\hline & Low & 3 & 2 & 20 & 20 & 15 & 15 & 10 & 80 \\
\hline & Totals & 32 & 30 & 248 & 248 & 186 & 186 & 124 & 992 \\
\hline
\end{tabular}

a vowel /a/ between the first two root consonants. The forms used in this study were the 3rd person masculine singular $(3 \mathrm{msg})$ gerundive, the $3 \mathrm{msg}$ infinitive and the imperative plural. The laryngeal and pharyngeal consonants $/ 2 \mathrm{~h}$ \& $\mathrm{h} /$, or 'gutturals', condition vowel lowering of $/ \mathrm{a} /$ to [a]. This pattern permitted generation of additional word types with [a]. Representative template shapes and examples are provided in Table 3.

In total, of the 137 target verbs, there were 87 different verb roots: 33 Type A (conjugated in both gerundive and imperative plural), 17 Type B (gerundive and infinitive), and 25 Type $\mathrm{C} /$ Type A with guttural (gerundive only). The target consonants were distributed as illustrated in Table 4.

Four repetitions of each token were planned for each speaker. However, not all speakers were able to complete four repetitions due to constraints of time. This amounted to two repetitions for Speaker 5 (S5), three for Speakers 3 and 4 (S3 and S4), and four for Speakers 2 and 1 (S2 and S1). Initial tokens were collected but not analyzed for this particular paper, because a word-boundary pause and supralaryngeal closure could not be distinguished based on acoustic evidence alone, thereby making conclusions about affrication tentative. However, we note that the silent interval has been interpreted as supralaryngeal closure in a recent study of word-initial affricates despite the potential ambiguity (Pycha 2009). Other features of initial /s'/ such as release duration, post-release laryngealization, amplitude rise slope, and rise time were important data to collect for a general descriptive overview of prevocalic $/ \mathrm{s} \%$, but the analysis of these data is left for future research. 
Disfluencies in a corpus this large were to be expected, however, the repeated-measures design compensated for this to a large extent. In a few cases some speakers did not produce a fluent token on any repetition, so the tokens were excluded even for speakers that did produce them. These included two tokens of $/ \mathrm{s} /$ and one each of $/ \mathrm{ss}^{\prime} /, / \mathrm{s}: /$, and $/ \mathfrak{t} \mathbf{g}^{\prime} /$. In these cases, speakers systematically produced an alveopalatal instead of an alveolar or vice versa.

\subsection{Measurements}

The tokens were analyzed using Praat 5.0.02 (Boersma 2001). Up to five acoustic landmarks were identified by a student annotator using a written protocol drawn up by the authors. The annotator took detailed notes of difficult and ambiguous tokens while segmenting data for a single speaker. The annotation for this speaker was reviewed, any ambiguities in the protocol were taken into account, and the protocol was revised to better suit potentially troublesome cases. Annotation of the first speaker's data, along with the rest, then commenced using the revised protocol. When the annotation was finished, the authors reviewed and corrected the annotation where necessary. The five intervals, as presented to the annotator, are described below:

Vowel 1 (V1): $\quad$ Measured in the acoustic waveform from the initiation of regular vibration to the beginning of high-amplitude periodic variation or a period marked by virtually no noise.

Closure (C): $\quad$ Period of virtually no noise from the point at which voicing is extinguished to the initiation of high amplitude aperiodic noise (frication) or the first transient burst followed by frication.

Release (R): $\quad$ High-amplitude aperiodic noise (can correspond to fricative, aspiration of a stop or second portion of an affricate).

Laryngealization $(\mathrm{Q})$ : Period of low-amplitude aperiodicity before the onset of voicing and initiation of regular vibration; marked by irregular vibration and lack of clear formant structure in the spectrogram (this was detected in both glottalic and pulmonic tokens).

Vowel 2 (V2): $\quad$ Measured from the initiation of regular vibration in the acoustic waveform to the point at which high-amplitude periodic variation in the oscillogram discontinues.

Figure 3 exemplifies several tokens with the (up to) five intervals labeled. Intervals were only labeled if the corresponding acoustic event actually occurred. Tokens were marked as 'problematic' if vowels were mispronounced or the utterance was otherwise disfluent.

Using a comprehensive script written by the first author, the following measurements were taken in Praat 5.0.02. Closure, release, and laryngealization duration were measured based on the boundaries chosen by the annotator. The RMS amplitude of the release was calculated in three $10 \mathrm{~ms}$ frames arrayed across each release. The left and right edges of the first and third frames were aligned with the beginning and end of the release. The second frame was positioned so that its center occurred at the center of the fricative. The content of each frame was transformed with a Hamming window. The values were normalized as a function of the average RMS intensity of the entire VCV sequence (measured using Praat's Get-root-mean-square function applied to the relevant annotated material), and a regression line was then fitted to the points. Finally, the slope of this line was calculated to indicate how the amplitude of release changed as a function of time (Mitani, Kitama \& Sato 2006; see Figure 4 below).

Rise-time of release was calculated by locating the absolute maximum amplitude of the release and determining the point in time when this event occurred (Johnson 2003). This measure was normalized by dividing the time stamp of maximum absolute amplitude by the duration of the entire release. 

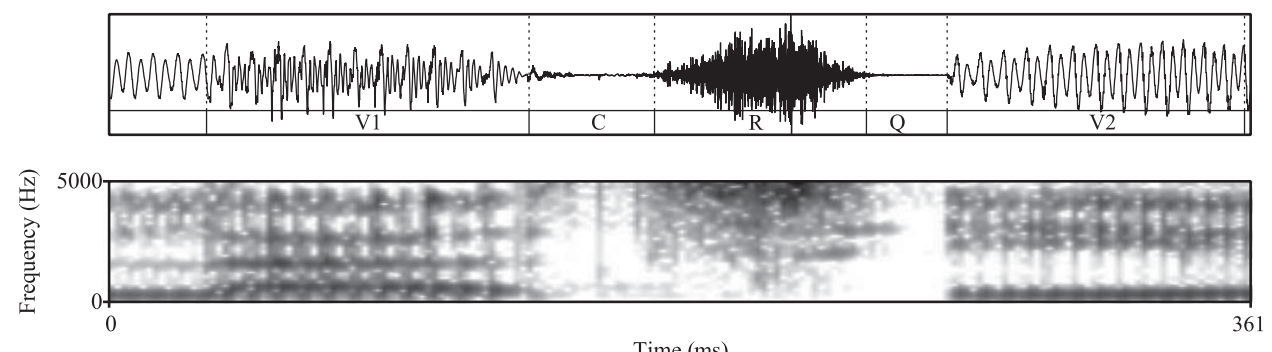

Time (ms)
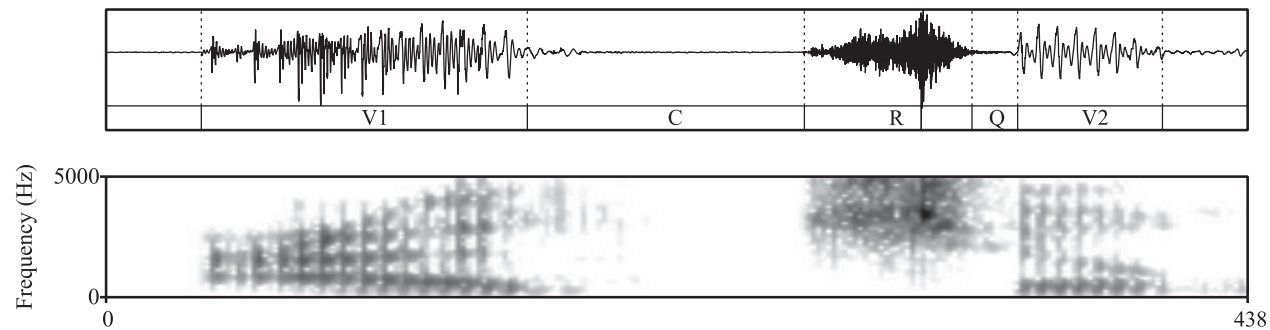

Time (ms)
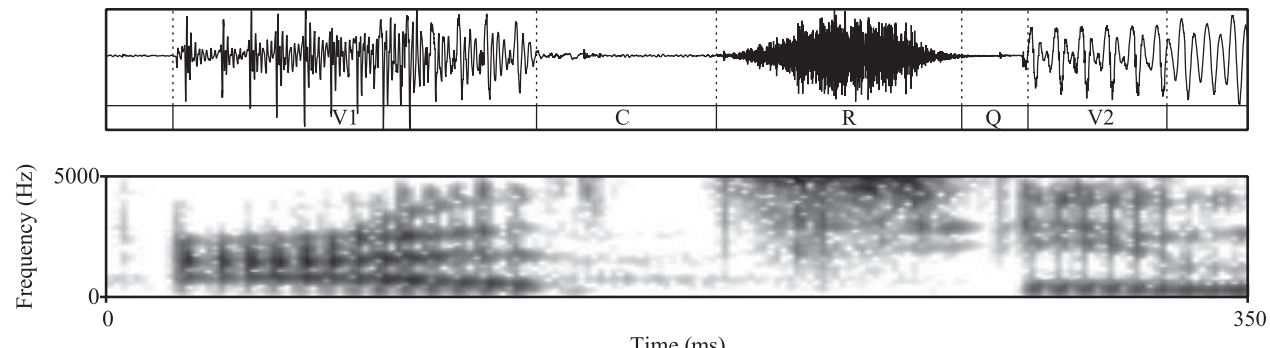

Time (ms)
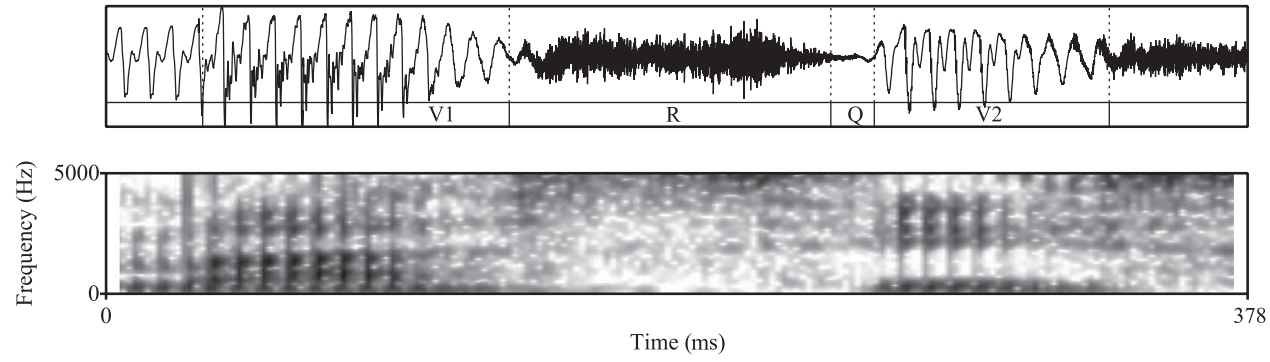

Figure 3 From top to bottom, the tokens [las'iju] 'he shaved', [Sat ' ix'u] 'he stuffed himself with food', [Sas':imu] 'it was hard and stiff' (uttered by S4), and [masisu] 'he caressed' (uttered by S3). Up to five intervals were labeled according to definitions set forth in Section 2.3: V1 = Vowel 1; $C=$ Closure; $R=$ Release; $Q=$ Post-release laryngealization; V2 = Vowel 2 .

\subsection{Statistical analysis}

Using the reshape function (Recast Package 0.8.3) in R 2.8.1, data frames were pre-processed for a repeated measures design: Measures for all repetitions of a single token uttered by a single speaker were averaged. Next, using R's Linear and Nonlinear Mixed Effects (NLME) Package 3.1-92, linear mixed effects (LME) models were fitted to the data by restricting maximum log likelihood (REML). For the LME models, Speaker was stipulated as a random effect. We chose not to use traditional linear models, because in this case Speaker is a factor without repeatable levels. It is generally recommended that so-called random effects terms (based on 
Table 5 Repeated measures averages with standard deviations in parentheses. Starred $\left(^{*}\right)$ units indicate some kind of normalization (see Section 2.3).

\begin{tabular}{llcccccccc}
\hline Manner & Airstream & Type & $\begin{array}{c}\text { V1 duration } \\
(\mathrm{ms})\end{array}$ & $\begin{array}{c}\text { Closure duration } \\
(\mathrm{ms})\end{array}$ & $\begin{array}{r}\text { Release duration } \\
(\mathrm{ms})\end{array}$ & $\begin{array}{c}\text { Laryngealized } \\
\text { duration }(\mathrm{ms})\end{array}$ & $\begin{array}{r}\text { V2 duration } \\
(\mathrm{ms})\end{array}$ & $\begin{array}{c}\text { Rise time (\%)* } \\
\text { Affricate }\end{array}$ & $\begin{array}{c}\text { Amplitude slope } \\
(\mathrm{dB} / \mathrm{s})^{*}\end{array}$ \\
\hline Fricative & Ejective & Geminate & $92(11)$ & $83(13)$ & $66(10)$ & $39(7)$ & $101(28)$ & $0.48(0.04)$ & $1.22(0.53)$ \\
& Ejective & Singleton & $95(9)$ & $69(8)$ & $67(7)$ & $33(8)$ & $82(17)$ & $0.50(0.04)$ & $1.11(0.47)$ \\
& Ejective & Geminate & $92(11)$ & $58(19)$ & $92(20)$ & $32(5)$ & $95(29)$ & $0.59(0.07)$ & $1.19(0.58)$ \\
& Ejective & Singleton & $97(13)$ & $45(17)$ & $90(13)$ & $31(5)$ & $89(28)$ & $0.57(0.08)$ & $1.17(0.56)$ \\
& Pulmonic & Geminate & $78(15)$ & $0(0)$ & $193(43)$ & $14(2)$ & $110(25)$ & $0.51(0.07)$ & $0.32(0.12)$ \\
& Pulmonic & Singleton & $83(11)$ & $0(0)$ & $125(11)$ & $14(1)$ & $91(21)$ & $0.49(0.06)$ & $0.31(0.17)$ \\
\hline
\end{tabular}

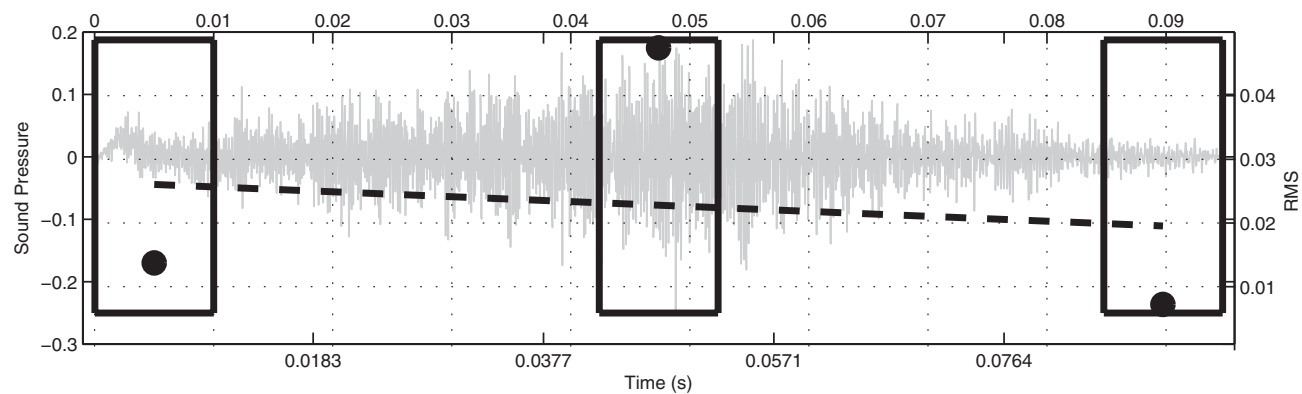

Figure 4 Method for calculating amplitude rise slope exemplified. The fricative is / s'/ from the word /las'iju/ 'he shaved'. The fricative was divided into three 10-ms frames and the RMS value of each frame was computed (the black dots). The dashed least-squares regression line represents the amplitude slope (in this case negative) of the fricative.

non-repeatable factors) be modeled as random effects, i.e. with a mean of zero and unknown variance (Baayen 2008: 241-242). LMEs have the advantage of incorporating factors that are repeatable (like Airstream) with factors that are non-repeatable (like Speaker). Chi-square tests were used to analyze raw count data, which were not averaged across repetitions.

Linear mixed effects models were designed for all fricatives with Airstream (pulmonic, ejective) as fixed effect, and Speaker/Airstream as a nested random effect (Laird \& Ware 1982). In relevant cases, Phonological Length was considered a fixed effect. Inspection of variables revealed that distributions for durations of V1, Closure (C), Release (R), Laryngealization (Q), and V2 were right-skewed. Duration variables were transformed logarithmically to better approximate a normal distribution.

\section{Results}

\subsection{Descriptive statistics: Repeated measures averages}

In this section, we report values from seven measurements with repeated measures averages (Table 5).

\subsection{Linear mixed effects models}

\subsubsection{Ejective and pulmonic fricatives}

Pulmonic fricative releases were longer than ejective fricative releases by a $5: 3$ ratio. Laryngealization was $13 \mathrm{~ms}$ after the pulmonic fricative but more than twice as long $(31 \mathrm{~ms})$ 
Table 6 Results of linear mixed effects models for fricatives with Airstream as fixed effect and Speaker as random effect.

\begin{tabular}{lccccc}
\hline Dependent variable & nDF & dDF & $\mathrm{F}$ & $\mathrm{p}(\mathrm{F})$ & Direction \\
\hline V1 duration (log) & 1 & 4 & 26.36 & $* *$ & $/ \mathrm{s}^{\prime} />/ \mathrm{s} /$ \\
Release duration (log) & 1 & 4 & 33.02 & $* *$ & $/ \mathrm{s}^{\prime} /</ \mathrm{s} /$ \\
Amplitude slope & 1 & 4 & 17.98 & $*$ & $/ \mathrm{s}^{\prime} />/ \mathrm{s} /$ \\
Laryngealized duration (log) & 1 & 3 & 107.65 & $* *$ & $/ \mathrm{s}^{\prime} />/ \mathrm{s} /$ \\
\hline
\end{tabular}

$*=p<.05 ; * *=p<.01$

$\mathrm{nDF}=$ numerator degrees of freedom; $\mathrm{dDF}=$ denominator degrees of freedom; $\mathrm{F}=\mathrm{F}$-statistic; $\mathrm{p}(\mathrm{F})=$ probability

\section{Fricatives}
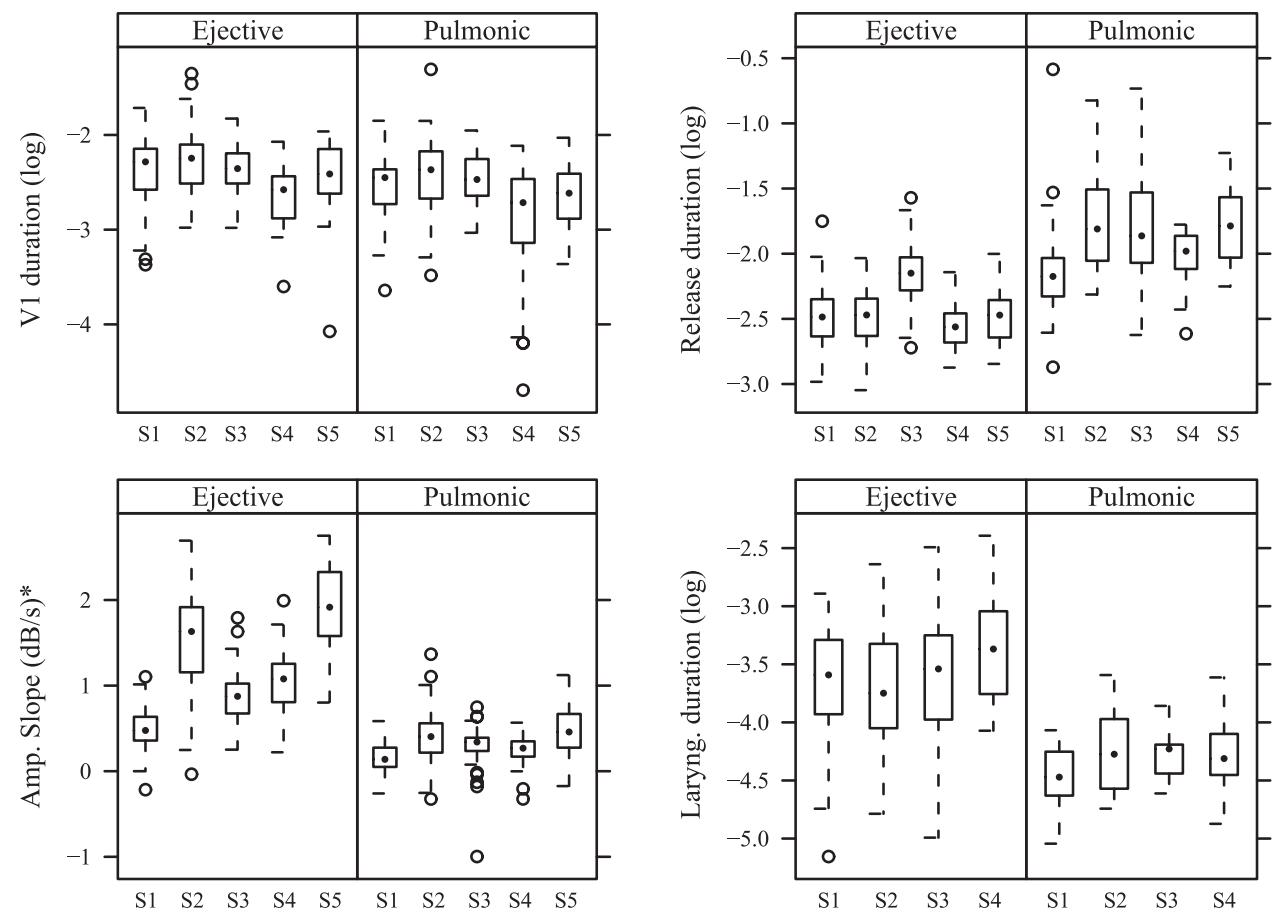

Figure 5 Repeated measures (averages) pertaining to mixed linear effects model presented in Table 6. X-axis labels are speaker identifiers.

for the ejective. Pulmonic releases were longer than ejective releases by $101 \mathrm{~ms}$ for geminates and $33 \mathrm{~ms}$ for singletons. Amplitude slope was greater for ejective than pulmonic fricatives. For ejective and pulmonic fricatives, closure duration could not be analyzed using a repeated measures design because no speakers produced pulmonic fricatives with closure. Only four speakers produced pulmonic fricatives with laryngealization. Details of the linear mixed effects models for fricatives are presented in Table 6 and Figure 5.

\subsubsection{Ejective fricatives and ejective affricates}

Using Manner as a fixed effect for ejective fricatives and affricates, it was shown that Manner is associated with closure duration, $F(1,4)=10.09(\mathrm{p}<.05)$ (see Figure 6). Closure duration was greater for affricates than fricatives by approximately $25 \mathrm{~ms}$ in the case of both singletons and geminates. 


\section{Ejectives}

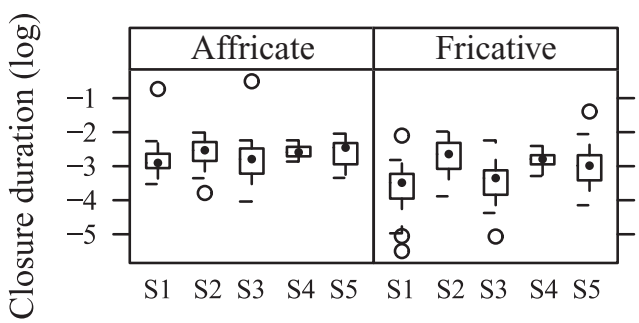

Figure 6 Boxplots of logarithmically-transformed closure duration for ejective fricatives and (ejective) affricates.

\section{Ejective Fricatives}

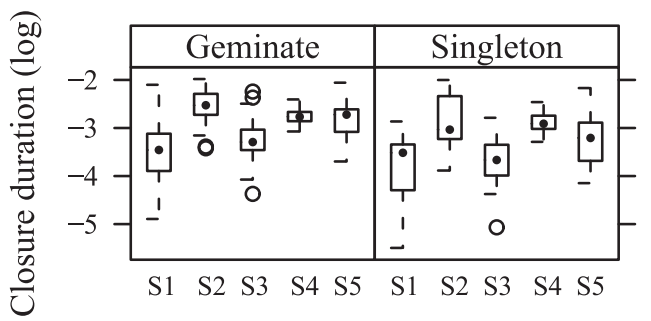

Figure 7 Boxplots of log-transformed closure duration of geminate and singleton ejective fricatives.

\subsubsection{Ejective fricatives}

Here we investigate the characteristics that differentiate phonological length among ejective fricatives. Closure duration was significantly longer for geminates than singletons (by about $13 \mathrm{~ms}), F(1,4)=34.31(\mathrm{p}<.01)$. Relevant boxplots are given in Figure 7.

For ejective fricatives alone, a linear mixed effects model was implemented with Presence of Closure as a fixed effect to better understand whether closure affects the acoustics of ejective fricatives. No significant effects were found for any measure.

\subsubsection{Ejective fricatives without closure and pulmonic fricatives}

$20 \%(66 / 327)$ of ejective fricatives in the corpus did not manifest closure. In this section, we address how ejective fricatives without closure differ from pulmonic fricatives. All ejective fricatives with closure were removed from the corpus and linear mixed models were used in a repeated measures design. This was complicated somewhat by the fact that S4 produced all ejective fricatives with closure, so his data were necessarily removed from the analysis. The purpose of the analysis was to judge the extent to which other acoustic cues may differentiate ejective and pulmonic fricatives in the absence of closure. Results are presented in Table 7 and Figure 8. Glottal duration was significantly longer for the no-closure ejective fricative than the pulmonic fricative and amplitude slope was significantly greater as well. This suggests that even in the absence of pre-release silence, there are other important cues signaling the difference between ejective and pulmonic fricatives.

\subsubsection{Ejective fricatives without closure and ejective affricates}

Ejective fricatives without closure and affricates were grouped together to determine the characteristics that differentiate them (besides the absence of closure). As in Section 3.2.4, S4's data were removed because all of his ejective fricatives manifested closure. Only release duration was associated with Manner, $F(1,3)=32.90(\mathrm{p}<.05)$. Release duration 
Table 7 Results of linear mixed effects models with Speaker as random effect. The corpus contains ejective fricatives with no closure (NC) and pulmonic fricatives.

\begin{tabular}{lccccc}
\hline Dependent variable & $\mathrm{nDF}$ & $\mathrm{dDF}$ & $\mathrm{F}$ & $\mathrm{p}(\mathrm{F})$ & Direction \\
\hline Laryngealized duration (log) & 1 & 3 & 33.24 & $*$ & $/ \mathrm{s} / \mathrm{NC}>/ \mathrm{s} /$ \\
Amplitude slope & 1 & 3 & 54.93 & $* *$ & $/ \mathrm{s}^{\prime} / \mathrm{NC}>/ \mathrm{s} /$ \\
\hline
\end{tabular}

$*=p<.05 ;{ }^{* *}=p<.01$

$\mathrm{nDF}=$ numerator degrees of freedom; $\mathrm{dDF}=$ denominator degrees of freedom; $F=F$-statistic; $\mathrm{p}(\mathrm{F})=$ probability

Table 8 Counts of ejective and pulmonic fricatives with respect to closure.

\begin{tabular}{lccc}
\hline & Pulmonic /s/ & Ejective /s'/ & Total \\
\hline No closure & 278 & 66 & 344 \\
Closure & 0 & 261 & 261 \\
Total & 278 & 327 & 605 \\
\hline
\end{tabular}

\section{Fricatives without closure}
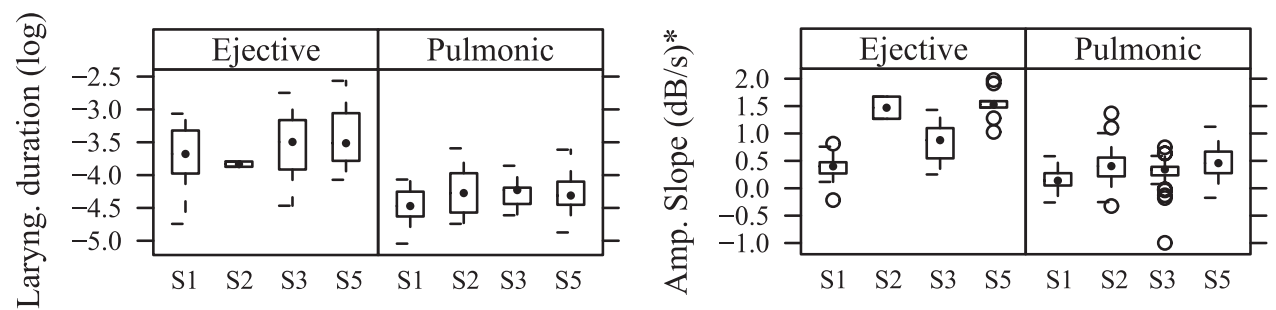

Figure 8 Boxplots relating to the linear mixed effects models presented in Table 7.

\section{Fricatives without closure + Affricates}

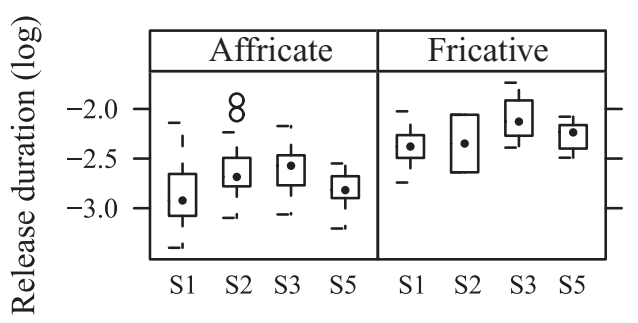

Figure 9 Boxplots pertaining to linear mixed effects models for fricatives without closure and affricates.

of no-closure ejective fricatives was on average $38 \mathrm{~ms}$ greater than the release duration of affricates (for geminates) and $45 \mathrm{~ms}$ greater for singletons. Relevant boxplots are presented in Figure 9.

\subsection{Count data: Presence of closure and laryngealization}

A Chi-square test was used to determine whether or not the proportions of pulmonic and ejective fricatives that manifested closure differed significantly. The results indicate that they did: $\chi^{2}(1, N=605)=569.15, \mathrm{p}<.001$. Counts for these variables are given in Table 8 . 
Table $\mathbf{9}$ Counts of ejective fricatives manifesting closure, grouped by phonological length.

\begin{tabular}{lccr}
\hline & Geminate /s:' & Singleton /s'/ & Total \\
\hline No closure & 19 & 47 & 66 \\
Closure & 145 & 116 & 261 \\
Total & 164 & 163 & 327 \\
\hline
\end{tabular}

Table 10 Counts of ejective fricatives and affricates with respect to closure.

\begin{tabular}{lrrr}
\hline & \multicolumn{1}{c}{$\mathbf{f}^{\prime} /$} & \multicolumn{1}{c}{$/ \mathbf{s}^{\prime} /$} & Total \\
\hline No closure & 5 & 66 & 71 \\
Closure & 216 & 261 & 477 \\
Total & 221 & 327 & 548 \\
\hline
\end{tabular}

Table 11 Counts of ejective and pulmonic fricatives with respect to laryngealization.

\begin{tabular}{lccc}
\hline & Pulmonic /s/ & Ejective /s'/ & Total \\
\hline No laryngealization & 173 & 7 & 180 \\
Laryngealization & 105 & 320 & 425 \\
Total & 278 & 327 & 605 \\
\hline
\end{tabular}

Table 12 Counts of ejective fricatives with respect to closure and laryngealization.

\begin{tabular}{lccr}
\hline & No laryngealization & Laryngealization & Total \\
\hline No closure & 2 & 64 & 66 \\
Closure & 5 & 256 & 261 \\
Total & 7 & 320 & 327 \\
\hline
\end{tabular}

Geminate ejective fricatives were significantly more likely than singleton ejective fricatives to manifest closure; $\chi^{2}(1, N=327)=14.05, \mathrm{p}<.001$ (Table 9).

Affricates were more likely to manifest closure than ejective fricatives; $\chi^{2}(1, N=548)=$ $35.98, \mathrm{p}<.001$ (Table 10).

Ejective fricatives were more likely to manifest laryngealization than pulmonic fricatives; $\chi^{2}(1, N=605)=256.72, \mathrm{p}<.001$ (Table 11$)$.

Just over $78 \%(256 / 327)$ of ejective fricatives manifested both closure and laryngealization, whereas only about $2 \%(5 / 327)$ of ejective fricatives manifested closure without laryngealization. Because ejective fricatives always manifested either closure or laryngealization, and because $20 \%$ (64/327) manifested laryngealization without manifesting closure, the relationship between closure and laryngealization for ejective fricatives alone was not significant; $\mathrm{p}>.05$ (Fisher's Exact Test for Count Data). These counts are listed in Table 12 .

\section{Discussion}

In support of the aeroacoustic affrication hypothesis, we find that phonological ejective fricatives are more likely to manifest pre-release silence than phonological pulmonic fricatives. Ejective fricatives manifest pre-release silence in $80 \%(261 / 327)$ of tokens. We interpret pre-release silence as linguopalatal closure on the basis of comparative palatographic and 
aerodynamic evidence in the related language Amharic (Demolin 2002, 2004). We do not, however, present conclusive physiological evidence for the realization of Tigrinya $/ \mathrm{s}^{\prime} / \mathrm{as}$ [ts'].

Affricate closure duration is on average $25 \mathrm{~ms}(50 \%)$ longer than ejective fricative closure, a statistically significant difference that may (in addition to place of articulation differences) help distinguish /s'/ from $/ \mathfrak{t}$ ' / or at least prevent /s'/ from undergoing reanalysis as /ts'

As predicted, closure duration differentiates phonological length for the ejective fricatives /s:'/ and /s'/ (by about $13 \mathrm{~ms}$ ). Closure duration also distinguishes geminate and singleton affricates by a margin of approximately $14 \mathrm{~ms}$ (see Table 5 above). The geminate ejective fricative /s:' was significantly more likely than the singleton ejective fricative / $/ \mathrm{s} /$ to manifest closure. We find that when closure is present geminate /s:'/ is realized as [t:s'], i.e. with a longer silent interval than the realization of singleton $/ \mathrm{s}^{\prime} / \rightarrow$ [ts']. This is reminiscent of findings by Pycha (2009: 21), who argues that among Hungarian affricates 'phonological lengthening exclusively increases closure duration' rather than release duration. To the extent that pre-release closure is associated with the phonological length of affricates (and our findings show that it is), we suggest that Tigrinya's ejective fricative, when accompanied by closure, is phonologically similar to an affricate.

For fricatives, pulmonic release is significantly longer than ejective release. The period of frication is $101 \mathrm{~ms}(110 \%)$ longer for pulmonic geminates and $34 \mathrm{~ms}(37 \%)$ longer for pulmonic singletons. This observation was expected and is supported by similar findings for Amharic (Demolin 2002, 2004) and Kabardian (Gordon \& Applebaum 2006). The effect has been attributed to the limited volume of air available between the glottis and supralaryngeal constriction for the ejective fricative. By contrast, pulmonic fricatives have access to a much larger volume of air contained in the lungs. Relatively high airflows are more sustainable during pulmonic fricatives (Maddieson 1997, Maddieson et al. 2001). Further aerodynamic research could shed light on this issue.

Release duration does not appear to signal phonological length among ejective fricatives. This result is intriguing, since release duration does distinguish geminate pulmonic fricatives from singleton pulmonic fricatives in Tigrinya as well as other languages, e.g. Swedish (Löfqvist 2005). Instead of release duration, it is closure duration that signals phonological length among Tigrinya ejective fricatives, much as it does for affricates in Hungarian (Pycha 2009). Release duration is not a significant cue for phonological length even among the subset of ejective fricatives that lack closure.

While our findings show that affrication occurs in a majority of ejective fricatives, this leaves a minority of ejective fricatives that are crucially not distinguished by closure before release. These tokens provide a window to acoustic cues (besides closure) that may signal ejectivity among fricatives, and also allow us to compare differences between [s'] and [ts'], both surface realizations of Tigrinya's ejective fricative $/ \mathrm{s} \%$. Release duration is one such acoustic cue, and pulmonic fricatives do still have longer release duration than ejective fricative tokens with no closure. However, release duration still contributes relatively little, if anything, to the phonological length distinction among ejective fricatives, even for the cases with no closure. This leads us to speculate that phonological length may be neutralized when ejective fricative closure is lost.

Laryngealization duration, or the amount of time it takes for regular vocal fold vibration to initiate after release, is significantly greater for ejective fricatives in relation to pulmonics, a characteristic also observed for other languages with ejective fricatives. This most likely stems from the increased time it takes for the larynx to lower from its elevated position and/or for the appropriate pressure differential across the glottis to be reached, thus giving rise to modal voicing. Fre Woldu (1985) demonstrates that this period of relative silence is the weightiest psychoacoustic cue in distinguishing pulmonic and ejective stops.

A considerable amount of variation has been reported in the VOT (voice onset time) of ejective stops. VOTs with an average of $12 \mathrm{~ms}$ have been reported in Abkhaz (Catford 1983) while a mean VOT of $108 \mathrm{~ms}(\mathrm{SD}=31)$ has been reported for coronal ejective stops in Navajo (McDonough \& Ladefoged 1993: 154). Our results show that the average post-release 
laryngealization (or VOT) of Tigrinya's alveolar ejective fricative is approximately $31 \mathrm{~ms}$. Kingston (1985) uses VOT as one of several parameters to typologize so-called tense and lax ejectives. ${ }^{8}$ The lax variety has shorter VOTs, so our study suggests that Tigrinya's ejective fricatives, at least in terms of this parameter, are 'lax'. VOTs measured by both Kingston (1985) and Fre Woldu (1985) seem to indicate that Tigrinya's stops are 'tense', i.e. they have longer VOT. Laryngealization, however, is present even among pulmonic fricatives, albeit at a significantly reduced frequency and duration. This non-ejective laryngealization most likely has its origin in the wide adduction of the vocal folds observed during the production of high-airflow voiceless fricatives like [s] (Ohala 1993: 158).

Laryngealization is present in almost all cases of ejective fricatives, whether they manifest closure or not. Indeed, there is no statistically significant relationship between laryngealization and closure among ejective fricatives. Thus, it is reasonable to suggest that, in the absence of closure, laryngealization still helps to signal the difference between ejective and pulmonic fricatives, just as it does when closure is present. While laryngealization usually occurs on [ts'] realizations of $/ \mathrm{s} \%$, ejective fricatives without closure still have significantly longer laryngealization than pulmonic fricatives.

Vowel duration also correlates with ejective vs. pulmonic fricative status. Vowel duration is significantly longer before ejective fricatives than pulmonic fricatives. This duration difference may be connected to compensation for the shorter release duration of ejective fricatives. We found no significant results for the vowel following the test consonant.

Amplitude slope (Mitani et al. 2006) is a measure of how quickly a release increases in its amplitude. We find that this measure is associated with airstream mechanism for Tigrinya fricatives. Ejective fricatives have a higher amplitude slope than pulmonic fricatives, meaning that, in effect, ejectives become louder more quickly than pulmonics. This is the case whether closure is present or not. High amplitude slope is associated with abrupt bursts and thus has been shown to differentiate affricates and fricatives (Weigelt, Sadoff \& Miller 1990; Mitani et al. 2006). Indeed, ejective fricative tokens with closure manifest higher amplitude slope than those without, in support of the affrication hypothesis. However, amplitude slope could not distinguish ejective fricatives and affricates in Tigrinya, whether or not the fricatives manifested closure.

The results for rise time, or the amount of time it takes to reach the sound pressure peak after release, were not significant. Long rise times are reportedly typical of fricatives, not affricates. Indeed, it has been claimed that rise time is a salient cue for the fricativeaffricate distinction (Cutting \& Rosner 1974, Howell \& Rosen 1983, Johnson 2003). Because we found rise time to be insignificant in distinguishing ejective fricatives from pulmonic fricatives, we wonder if the predictions of Howell \& Rosen's (1983) model hold only for consonants produced by the same airstream mechanism (Cutting \& Rosner 1974 and Howell \& Rosen 1983 investigated pulmonics only). Indeed, to the extent that the so-called 'pulsing' or 'scrapy' quality is a characteristic of Tigrinya ejective fricatives, Howell \& Rosen's model (designed for smoothly rising amplitudes) may be inappropriate. We make no quantitative observations regarding the presence or absence of this 'scrapy' quality among Tigrinya ejective fricatives because we are unsure how to quantify this attribute. It is not clear, for example, whether the 'pulses' in an ejective fricative would be of roughly equal amplitude. Without knowing this, it seems an intractable problem to conclude whether the mathematical maximum is indeed the 'true' maximum amplitude of the fricative. Without a basic definition of what differentiates a 'pulse' of an ejective fricative from an otherwise noisy envelope, we doubt whether 'scrapiness' can be used in any consistent or falsifiable way (as noted earlier, the scrapy quality may arise from pharyngeal constriction; Esling 1996, Moisik 2008). We

\footnotetext{
${ }^{8}$ Kingston's (1985) typology has been criticized by Wright, Hargus \& Davis (2002), who proposed that it 'may underestimate the complexities of laryngeal muscular adjustment, aerostatic-myoelastic interactions, and timing relationships involved in the production of ejectives' (pp. 70-71).
} 
note that more recent studies have challenged Cutting \& Rosner (1974) and Howell \& Rosen (1983) on the issue of rise time. For example, both Diehl \& Castleman (1996) and Kluender \& Walsh (1992) consider rise time an insufficient cue for distinguishing fricatives and affricates. Unfortunately, our results shed no further light on the issue.

In a majority $(80 \%)$ of tokens, Tigrinya's ejective fricative $/ \mathrm{s}$ / shows evidence of closure, a characteristic shared with affricates. The pre-release closure is significantly shorter than the pre-release closure of the phonological ejective affricate; moreover, closure is not present in all of the tokens recorded. However, closure duration, not release duration, signals the difference between singleton and geminate ejective fricatives, a pattern shared with affricates. Conversely, pulmonic fricatives manifest length contrast through release duration. Besides closure duration, ejective fricatives are distinguished from pulmonic fricatives by a number of characteristics including preceding vowel duration, release duration, and amplitude slope. Ejective fricatives are also typified by a greater likelihood of post-release laryngealization. Based on this evidence it would be premature to categorically reclassify Tigrinya $/ \mathrm{s} /$ as an affricate, primarily because pre-release silence does not occur in all tokens and there are several other acoustic cues signaling the difference between ejective and pulmonic fricative (not least of all is release duration). However, it seems reasonable to cite Tigrinya $/ \mathrm{s}$ ' $\rightarrow$ [ts'] as an example of a phonetically-natural, aerodynamically-conditioned sound change in progress. Because Tigrinya has no homorganic affricate to pair with $/ \mathrm{s}^{\prime} /$, the production of [ts'] has no consequence on the phonological inventory of the language, e.g. creating pressure on a hypothetical /ts'/ phoneme. As shown, however, there are phonological implications for the realization of quantity when it comes to Tigrinya $/ \mathrm{s}^{\prime} /$ : instead of increasing release duration, as is typical of long fricatives, Tigrinya's phonologically long $/ \mathrm{s} /$ is realized with a lengthened closure, typical of affricates (Pycha 2009).

\section{Conclusion}

The realization of ejective fricatives tests the limits of human vocal production by combining two production mechanisms that, from a certain point of view, seem irreconcilable: ejectivity and frication. Based on the typological rarity of the sound, one might conclude that its production characteristics make it unstable across generations of speakers. However, this would miss the interesting typological and phonetic relationship between ejective fricatives and affricates known to exist in the languages of the world. If we sample only those languages that have ejective obstruents, the subset of those languages with ejective affricates is more likely to have ejective fricatives than a subset without ejective affricates. A brief inspection of the design of the human vocal tract and the requirements of ejectivity lead us to believe that this is not by chance. After all, the best way to realize an ejective is to seal and compress the column of air between the glottis and an oral closure; the best way to realize a fricative is to continuously vent air from the vocal tract. Thus it is not surprising that, for ejective fricatives, we see variation precisely in terms of the seal's presence or absence.

Transcriptions of Tigrinya are remarkably variable in capturing the realization of $/ \mathrm{s} \%$. This can be attributed either to misperception on the part of the linguists who have documented Tigrinya or actual variation in the realization of the consonant across dialects, speakers, and words. We have shown instrumentally that variation indeed exists. Since Tigrinya also happens to have the ejective affricate $/ \mathfrak{t}$ '/, our analysis focused on the acoustic differences between the fricative and the affricate and between forms of the ejective fricative realized with and without closure. In reaching our conclusion that Tigrinya's ejective fricative is generally realized as an affricate, we are aware that the greatest challenge in extending our results to other languages is that Tigrinya itself does not have a phonemic ejective fricative and a phonemic ejective affricate at the same place of articulation. To understand whether affrication of ejective fricatives is widespread, a useful study would be to test the phonetic 
differences (if any) between ejective fricatives and affricates at the same place of articulation, e.g. in Mazahua, Tlingit, and Yuchi (all of which have /s' ts'/), Kabardian (/s's' tšn'/), or Acoma (/ts's's') (Maddieson 1984).

We conclude that ejective fricatives in Tigrinya are frequently realized with complete oral occlusion before release, a point that awaits further verification using EPG technology. While affrication satisfies the unique aeroacoustic demands of ejectivity, it simultaneously changes the category of /s'/ from fricative to affricate. The absence of an ejective affricate at the same place of articulation arguably gives speakers of Tigrinya the freedom to variably affricate $/ \mathrm{s}^{\prime} \%$. The path from realization of [s'] to [ts'] seems natural, though it is unclear how long or whether a stable phonological distinction can truly be maintained between the two. This necessarily raises interesting questions about the $1.3 \%(6 / 451)$ of the world's languages (Maddieson \& Precoda 1991) that reportedly maintain such an opposition and sets the bar higher for fully describing their acoustic, aerodynamic, and articulatory production.

\section{Acknowledgements}

We are very grateful to the Tigrinya speakers who participated in this study: Aki Ghebre, Marco Pedulli, Saad Ali, Teamrat Adhanom, Zerai Araia and Beraki Woldeabzghi. We thank John Esling and two anonymous reviewers for their helpful comments and suggestions on earlier versions of this manuscript. We acknowledge the comments and questions of audience members at the annual meetings of the LSA (2008) and NACAL (2008), in particular Gene Buckley, Scott Henderson, Grover Hudson, and Ian Maddieson. Melinda Fricke and Megan Osfar provided valuable service as research assistants. All errors and omissions are entirely our responsibility.

\section{References}

Baayen, R. Harald. 2008. Analyzing linguistic data: A practical introduction to statistics using $R$. Cambridge: Cambridge University Press.

Ballard, William L. 1975. Aspects of Yuchi morphonology. In James M. Crawford (ed.), Studies in Southeastern Indian languages, 164-187. Athens, GA: University of Georgia Press.

Beck, David. 2006. The emergence of ejective fricatives in Upper Necaxa Totonac. In Robert Kirchner (ed.), University of Alberta Working Papers in Linguistics 1, 1-18.

Bender, M. Lionel. 1992. Amharic. In William Bright (ed.), International encyclopedia of linguistics, 51-56. New York: Oxford University Press.

Berhane, Girmay. 1991. Issues in the phonology and morphology of Tigrinya. Ph.D. dissertation, Université du Québec à Montréal.

Boas, Franz \& Ella Deloria. 1939. Dakota grammar (Memoirs of the National Academy of Sciences 23.2). Washington, DC.

Boersma, Paul. 2001. Praat: A system for doing phonetics by computer. Glot International 5, 341-345.

Bucella, Fabrizio, Sergio Hassid, Renaud Beeckmans, Alain Soquet \& Didier Demolin. 2000. Pression sous-glottique et débit d'air buccal des voyelles en français. Actes des XXIIIèmes Journées d'Etude sur la Parole, 449-452. Aussois.

Catford, J. C. 1992. Caucasian phonetics and general phonetics. In Catherine Paris (ed.), Caucasologie et mythologue comparée. Actes du Colloque International C.N.R.S. IV Colloque de Caucasologie, 193-216. Paris: Peeters.

Catford, J. C. 1983. Pharyngeal and laryngeal sounds in Caucasian languages. In Diane M. Bless \& James H. Abbs (eds.), Vocal fold physiology: Contemporary research and clinical issues, 344-350. San Diego, CA: College Hill Press.

Catford, J. C. 2001. A practical introduction to phonetics, 2nd edn. New York: Oxford University Press.

Crawford, James M. 1973. Yuchi phonology. International Journal of American Linguistics 39, 173-179.

Crystal, David. 2003. A dictionary of linguistics and phonetics, 5th edn. Oxford: Wiley-Blackwell. 
Cutting, James E. \& Burton S. Rosner. 1974. Categories and boundaries in speech and music. Perceptual Psychophysics 16(3), 564-570.

Dauenhauer, Nora Marks \& Richard Dauenhauer. 1991. Beginning Tlingit, 3rd edn. Juneau, AK: Sealaska Heritage Foundation Press.

Demolin, Didier. 2002. The search for primitives in phonology and the explanation of sound patterns: The contribution of fieldwork studies. In Carlos Gussenhoven \& Natasha Warner (eds.), Laboratory phonology 7, 455-514. The Hague: Walter de Gruyter.

Demolin, Didier. 2004. Acoustic and aerodynamic characteristics of ejectives in Amharic. Journal of the Acoustical Society of America 115(5), 2610.

Denais, Michel. 1990. Eléments de phonologie et de morphologie Tigrigna. Ph.D. dissertation, Université de Nice Sophia Antipolis.

Diehl, Randy L. \& Wendy A. Castleman. 1996. Integrated perceptual properties: The affricate/fricative distinction. In Adrian P. Simpson \& Matthias Pätzold (eds.), Sound patterns of connected speech: Proceedings of a symposium held at Kiel University, 191-200.

Esling, John H. 1996. Pharyngeal consonants and the aryepiglottic sphincter. Journal of the International Phonetic Association 26, 65-88.

Esling, John H., Katherine E. Fraser \& Jimmy G. Harris. 2005. Glottal stop, glottalized resonants, and pharyngeals: A reinterpretation with evidence from a laryngoscopic study of Nuuchahnulth (Nootka). Journal of Phonetics 33, 383-410

Faber, Alice. 1985. Akkadian evidence for Proto-Semitic affricates. Journal of Cuneiform Studies 37(1), 101-107.

Faber, Alice. 2007. Genetic subgrouping of the Semitic languages. In Robert Hetzron (ed.), The Semitic languages, 3-15. New York: Routledge.

Fitzgerald, Colleen. 2006. More on phonological variation in Tigrinya. In Siegbert Uhlig (ed.), 15th International Conference on Ethiopian Studies, 763-768. Wiesbaden: Harrassowitz.

Fleming, Harold. 1990. A grammatical sketch of Dime (Dim - Af) of the lower Omo. In Richard Hayward (ed.), Omotic language studies, 494-583. London: School of Oriental and African Studies, University of London.

Fre Woldu, Kiros. 1985. The perception and production of Tigrinya stops (Reports from Uppsala University Department of Linguistics 13). Uppsala: Uppsala University.

Garvin, Paul L. 1950. Wichita I: Phonemics. International Journal of American Linguistics 16, 179-184.

Gordon, Matthew \& Ayla Appelbaum. 2006. Phonetic structures of Turkish Kabardian. Journal of the International Phonetic Association 36(2), 159-186.

Howell, Peter \& Stuart Rosen. 1983. Production and perception of rise time in the voiceless affricate/ fricative distinction. Journal of the Acoustical Society of America 73(3), 976-984.

Jaggar, Phillip. 2001. Hausa. Amsterdam \& Philadelphia: John Benjamins.

Jensen, John. 1977. Yapese reference grammar. Honolulu, HI: The University Press of Hawaii.

Johnson, Keith. 2003. Acoustic and auditory phonetics, 2nd edn. Oxford: Blackwell.

Johnstone, Thomas M. 1975. The modern South Arabian languages. Afroasiatic Linguistics 1, 93-121.

Kane, Thomas. 2000. Tigrinya-English dictionary. Kensington, MD: Dunwoody Press.

Kenstowicz, Michael. 1982. Gemination and spirantization in Tigrinya. Studies in the Linguistic Sciences $12,103-122$

Kingston, John. 1985. The phonetics and phonology of the timing of oral and glottal events. Ph.D. dissertation, University of California at Berkeley.

Kluender, Keith R. \& Margaret A. Walsh. 1992. Amplitude rise time and the perception of the voiceless affricate/fricative distinction. Perceptual Psychophysics 51(4), 328-333.

Kogan, Leonid. 1997. Tigrinya. In Robert Hetzron (ed.), The Semitic languages, 424-445. New York: Taylor \& Francis.

Kuipers, Aert. 1960. Phoneme and morpheme in Kabardian (Eastern Adyghe). The Hague: Mouton.

Ladefoged, Peter. 1993. A course in phonetics, 3rd edn. Fort Worth, TX: Harcourt Brace College.

Ladefoged, Peter \& Ian Maddieson. 1996. The sounds of the world's languages. Oxford: Blackwell.

Laird, Nan M. \& James H. Ware. 1982. Random-effects models for longitudinal data. Biometrics 38, 963-974. 
Leslau, Wolf. 1938. Lexique socotri. Paris: Klincksieck.

Leslau, Wolf. 1939. Observations sur quelques dialectes du Tigrigna: Dialectes d'Akkele Gouzay, d'Adoua, et du Hamasen. Journal Asiatique 231, 61-115.

Leslau, Wolf. 1941. Documents Tigrigna (Éthiopien Septentrional): Grammaire et textes. Paris: Librairie C. Klincksieck.

Leslau, Wolf. 1957. Observations on a comparative phonology of Semitic languages. Annales d'Ethiopie 2, $147-166$.

Leslau, Wolf. 1987. Comparative dictionary of Ge'ez (Classical Ethiopic). Wiesbaden: Otto Harrassowitz.

Leslau, Wolf. 1995. A reference grammar of Amharic. Wiesbaden: Harrassowitz.

Lindsey, Geoffrey, Katrina Hayward \& Andrew Haruna. 1992. Hausa glottalic consonants: A laryngographic study. Bulletin of the School of Oriental and African Studies 55(3), 511-527.

Löfqvist, Anders. 2005. Lip kinematics in long and short stop and fricative consonants. Journal of the Acoustical Society of America 117(2), 858-878.

Maddieson, Ian. 1984. Patterns of sounds. Cambridge: Cambridge University Press.

Maddieson, Ian. 1997. Combining frication and glottal constriction: Two solutions to a dilemma. Journal of the Acoustical Society of America 102(5), 3135.

Maddieson, Ian. 1998. Why make life hard? Resolutions to problems of rare and difficult sound types. UCLA Working Papers in Phonetics 96, 106-118. [Also published in Proceedings of the Annual Meeting of the Berkeley Linguistic Society 24, 367-380.]

Maddieson, Ian, Heriberto Avelino \& Loretta O'Connor. 2009. The phonetic structures of Oaxaca Chontal. International Journal of American Linguistics 75, 69-101.

Maddieson, Ian \& Kristin Precoda. 1991. UPSID-PC: The UCLA Phonological Segment Inventory Database. http://www.linguistics.ucla.edu/faciliti/sales/software.htm (retrieved 11 January 2008).

Maddieson, Ian, Caroline L. Smith \& Nicola Bessell. 2001. Aspects of the phonetics of Tlingit. Anthropological Linguistics 43(2), 135-176.

McDonough, Joyce \& Peter Ladefoged. 1993. Navajo stops. UCLA Working Papers in Phonetics 84, $151-164$

Miller, Wick R. 1966. Acoma grammar and texts. Berkeley \& Los Angeles, CA: University of California Press.

Mitani, Shigeki, Toshihiro Kitama \& Yu Sato. 2006. Voiceless affricate/fricative distinction by frication duration and amplitude rise slope. Journal of the Acoustical Society of America 120(3), 1600 1607.

Moisik, Scott R. 2008. A three-dimensional model of the larynx and the laryngeal constrictor mechanism: Visually synthesizing pharyngeal and epiglottal articulations observed in laryngoscopy. MA thesis, University of Victoria.

Mous, Maarten. 1993. A grammar of Iraqw. Hamburg: Busker.

Newman, Paul C. 2000. The Hausa language: An encyclopedic reference grammar. New Haven, CT: Yale University Press.

Ohala, John J. 1993. Sound change as nature's speech perception experiment. Speech Communication 13, $155-161$.

Palmer, Frank R. 1962. The morphology of the Tigre noun. London: Oxford University Press.

Palmer, Frank R. 1966. The 'broken plurals' of Tigrinya. Bulletin of the School of Oriental and African Studies 17, 548-566.

Pam, Martin David. 1973. Tigrinya phonology. Ph.D. dissertation, City University of New York.

Pycha, Anne. 2009. Lengthened affricates as a test case for the phonetics-phonology interface. Journal of the International Phonetic Association 39(1), 1-31.

Raz, Shlomo. 1983. Tigre grammar and texts. Malibu: Undena Publications.

Rood, David. 1975. The implications of Wichita phonology. Language 51, 315-337.

Savà, Graziano. 2005. A grammar of Ts'amakko. Köln: Rüdiger Köppe.

Schein, Barry. 1981. Spirantization in Tigrinya. In Hagit Borer \& Youssef Aoun (eds.), MIT Working Papers in Linguistics 3: Theoretical Issues in the Grammar of Semitic Languages, 32-42. Cambridge, MA: MIT. 
Seyoum, Mulugeta. 2008. A grammar of Dime. Utrecht: LOT.

Simeone-Senelle, Marie-Claude. 1997. The modern South Arabian languages. In Robert Hetzron (ed.), The Semitic languages, 378-423. New York: Taylor \& Francis.

Spotts, Hazel. 1953. Vowel harmony and consonant sequences in Mazahua (Otomi). International Journal of American Linguistics 19, 253-258.

Steiner, Richard. 1982. Affricated Sade in the Semitic languages. New York: American Academy for Jewish Research.

Story, Gillian L. \& Constance M. Naish. 1973. Tlingit verb dictionary. Fairbanks, AK: Alaska Native Language Center, University of Alaska.

Suárez, Jorge. 1983. The Mesoamerican languages. Cambridge: Cambridge University Press.

Swanton, John R. 1911. Tlingit. In Franz Boas (ed.), Handbook of American Indian languages part 1 (Bureau of American Ethnology Bulletin 40), 425-559. Washington, DC: Smithsonian Institution.

Tadesse, Takkele. 1992. Are s' and t' variants of an Amharic variable? A sociolinguistic analysis. Journal of Ethiopian Languages and Literature 2, 104-121.

Teston, Bernard \& Benoît Galindo. 1990. Physiologia: Un logiciel d'analyse des paramètres physiologiques de la parole. Travaux de l'Institut de Phonétique d'Aix 13, 197-217.

Tewolde, Tesfay Yohannes. 2002. A modern grammar of Tigrinya. Rome: U. Detti.

Triulzi, Alessandro, Atieb A. Dafallah \& M. Lionel Bender. 1976. Berta. In M. Lionel Bender (ed.), The non-Semitic languages of Ethiopia, 513-532. East Lansing, MI: African Studies Center, Michigan State University.

Tucker, Archibald N. \& Margaret A. Bryan. 1966. Linguistic analyses: the non-Bantu languages of northeastern Africa. London: Oxford University Press for International African Institute.

Ullendorff, Edward. 1955. The Semitic languages of Ethiopia: A comparative phonology. London: Taylor's Press.

Voigt, Rainer. 1988. Labialization and the so-called sibilant anomaly in Tigrinya. Bulletin of the School of Oriental and African Studies 51, 525-536.

Walther, Markus. 1999. Deklarative prosodische Morphologie: Constraint-basierte Analysen und Computermodelle zum Finnischen und Tigrinya. Tübingen: Niemeyer.

Waterhouse, Viola. 1962. The grammatical structure of Oaxaca Chontal. International Journal of American Linguistics 28(2), 1-114.

Waterhouse, Viola. 1967. Huamelultec Chontal. In Norman A. McQuown (ed.), Handbook of Middle American Indians, vol. 5: Linguistics, 349-367. Austin, TX: University of Texas Press.

Weigelt, LaDeana F., Steven J. Sadoff \& James D. Miller. 1990. Plosive/fricative distinction: The voiceless case. Journal of the Acoustical Society of America 87(6), 2729-2737.

Whiteley, Wilfred H. 1958. A short description of item categories in Iraqw. Kampala: East African Institute of Social Research.

Wright, Richard, Sharon Hargus \& Katharine Davis. 2002. On the categorization of ejectives: Data from Witsuwit'en. Journal of the International Phonetic Association 32(1), 43-77. 